\title{
The Cultural, Economic and Technical Milieu of Social Media Misconduct Dismissals in Australia and South Africa
}

By René Cornish, (PhD Candidate at the Queensland University of Technology School of Law), Orchid: https://orcid.org/0000-0002-0859-3280 and Kieran Tranter, (Chair of Law, Technology and Future at Queensland University of Technology School of Law), Orchid: https://orcid. org/0000-0003-1683-2939

Queensland University of Technology, Brisbane

\begin{abstract}
The intersection between social media activity and employment is an emerging global issue. This article examines the cultural, economic and technical milieu that has generated contested social media misconduct dismissals in Australia and South Africa. Through an analysis of 42 Australian and 97 South African decisions, it is argued that the ubiquitous, enduring and open nature of social media affects employment quite differently depending on country specific factors. In Australia, the absence of entrenched political rights has meant that employee social media use is not subject to reasonable expectations of privacy. However, there is also tolerance for a certain level of larrikin behaviour. In South Africa, the existence of enshrined rights manifests differently in the context of social media dismissal. Within a culturally diverse population with deeply fractured race relations, the decisions reveal a White minority still perpetuating dominance over a historically disadvantaged Black workforce.
\end{abstract}

Keywords - Employment, Dismissal, Social Media, Facebook and Twitter

\footnotetext{
Acknowledgements. We would like to thank the anonymous reviewers for their detailed and insightful comments.

Disclosure statement - No potential conflict of interest was reported by the author.

License - This work is under Attribution-NonCommercial-ShareAlike 4.0 International (CC BY-NC-SA 4.0) https://creativecommons.org/licenses/by-nc-sa/4.0/

Suggested citation: René Cornish and Kieran Tranter, "The Cultural, Economic and Technical Milieu of Social Media Misconduct Dismissals in Australia and South Africa" Law in Context, 36 (2): 17-48. DOI: https://doi.org/10.26826/law-in-context.v36i2.113
}

\section{INTRODUCTION}

In the space of 10 years social media has become a significant factor in human life. The 2016 US Presidential election has particularly turned attention to the impact of social media - as media - on public institutions and public trust (Sunstein 2018). Simultaneously, there has emerged significant literature focused on the impact of social media on individuals, from their sense of wellbeing and mental health to their feelings of security and optimism for the future. ${ }^{1}$ One of the obvious impacts of social media is where claims of social media misconduct by employees is used by employers as the basis for dismissing the employee (Davis 2015).

${ }^{1}$ On the changing emphasises and concerns with social media, see generally Lomborg (2017). 
The primary focus of this growing literature and knowledge about the impacts of social media has been nations with developed economies. A mostly unmentioned and unmediated upon assumption has been that social media and its consequencessuch as employment dismissal for social media misconduct-is a problem only within the Global North where digital technologies and infrastructure are well established. Limiting social media and its impact to the Global North ignores the substantial diffusion of digital communication into the Global South and with it ignores how these technologies are shaping and disrupting these societies, economies and cultures.

Global statistics indicate that there are approximately 3.48 billion active social media users worldwide (Global Digital Report 2019) with almost 1.23 billion users connecting on social media platforms daily. ${ }^{2}$ In Australia, a nation that is usually considered part of the Global North, ${ }^{3} 79 \%$ of the population use social media (Yellow Social Media Report 2018) ${ }^{4}$ and in South Africa, a nation considered belonging to the Global South, ${ }^{5} 40 \%$ of the population are active social media users, with $38 \%$ being mobile social media users (Global Digital Report 2019). While there is still a noticeable gap in overall percentages, the diffusion of social media in Africa is accelerating due to increases in mobile cellular connectivity and the reduced costs of digital devices (Tchamyou, Erreygers and Cassimon 2019). Indeed, recent figures indicate that there are 216 million active social media users in Africa (Global Digital Report 2019, p. 12).

Further, these users are intensely accessing social media. In South Africa the average time per day that a user is engaging with a social media platform is two hours forty-eight minutes (Global Digital Report 2019, p. 77). That is significantly higher than the Australian average of one hour thirty-one minutes (Global Digital Report 2019, p. 77). Clearly, in South Africa, there is a large and increasingly engaged population of social media users, and it would be expected that it would be generating similar challenges for employment law and policies as has been seen in Global North nations like Australia.

This article aims to begin to address this imbalance. Focusing on social media misconduct dismissal in Australia and South Africa, it identifies how social media use is filtered through very specific national contexts to produce discrete concerns. In Australia social media misconduct is not mitigated by any constitutionally entrenched rights of privacy and freedom of speech, yet a certain degree of "larrikin" joking seems tolerated.
In South Africa, an elaborate regime of rights does not translate into protections for employees. Rather the rights-based system seems to reinforce established racial and economic divides. These findings came from an examination of the available decisions of first instance, lower level employment tribunals and appeals from those tribunals to the general courts. The Australian sample comprised 42 decision; the South African sample was 97 decisions. These were analysed following similar socio-legal studies as windows into the cultural, economic and technical milieu that gives rise to social media misconduct dismissals.

The structure of the article is as follows. The next section locates the analysis within existing studies of social media misconduct dismissals; particularly highlighting that there are few comparative studies and very few studies looking at the Global South. This section also sets out the research method and explains how the samples were collected and analysed. The third section presents findings where there was no particular difference between the Australian and South African samples. There were cases where social media content was used as documentary evidence of employee infractions "at work." Another commonality was how rights-based arguments had little traction in both jurisdictions. While this finding was unsurprising in Australia given the absence of a formal rights instrument at the Commonwealth level; it was surprising in South Africa with its entrenched system of rights. The fourth section presents what was unique in the samples; how in the Australian sample there was a degree of tolerance for larrikin behaviour and how social media misconduct dismissal in South Africa is fundamentally racialised.

\section{SOCIAL MEDIA MISCONDUCT DISMISSAL AND METHOD}

This section argues that while there is a significant literature looking at social media misconduct dismissal, there are two gaps. The first is a preponderance of studies focused on superior courts from a single jurisdiction. While this reveals the state of the law in the jurisdiction, by not considering primary decisions, these studies tend to de-emphasis the cultural, economic and technical milieu surrounding social media misconduct dismissal. The second is that, while there are some comparative studies, most of these have been limited to Global North nations. The impact of social media within employment in developing nations has generally been absent. This section

\footnotetext{
${ }^{2}$ https://www.socialmedianews.com.au/social-media-statistics-australia-september-2019/

${ }^{3}$ On Australia as interloper of the Global North in the geographical South see Mann and Daly (2019).

${ }^{4}$ See also https://www.sensis.com.au/about/our-reports/sensis-social-media-report and https://www.yellow.com.au/wp-content/uploads/2018/06/Yellow-Social-MediaReport-2018-Consumer.pdf

${ }^{5}$ On Australia and South Africa as Global North and South see Odeh (2012).
} 
will also introduce the study through reviewing similar sociolegal studies that have used primary "street-level" decisions to gain an insight into the cultural, economic and technical milieu that give rise to legal disputes and outlining how the samples were identified and analysed.

In Australia, there have been several high profile dismissals for "off duty" social media misconduct including McIntyre $v S B S,{ }^{6}$ the suspension of La Trobe University educator Roz Ward $^{7}$, Williams v Cricket Australia ${ }^{8}$ and the most recent case of Israel Folau $v$ Rugby Australia..$^{9}$ Internationally, the dismissal of Justine Sacco attained international notoriety ${ }^{10}$ when prior to boarding an aircraft from London to Cape Town she tweeted a racially abhorrent comment that went viral before she landed in South Africa. Foremost, these matters show that employment law does regard social media as evidence of inappropriate employee behaviour (Van Dissel 2014; Thornthwaite 2013). Furthermore, commentators tend to identify several features. The first that social media is depicted as a boundless (Van Dissel 2014) "non-place" (Richardson, Thomas and Trabsky 2012, p. 257) free of "temporal" and "spatial" limits (Banghart, Etter and Stohl 2018, p. 337). The second is that social media has an endurance and permeability; leaving a digital archive of not only the post but also reactions to it (Potgieter 2014; Lindsay 2014; Cilliers 2014; Sleep and Tranter 2018). The third is that contemporary employment should be seen as extending beyond physical structures (McDonald and Thompson 2016) and defined hours to being "everywhere and every when" (Van Gramberg, Teicher and O'Rouke 2014, p. 2235).

Although these high-profile matters were settled in confidence, such as the recent Folau matter, ${ }^{11}$ there is literature that identifies a growing body of employment decisions pertaining to social media misconduct dismissal in Australia (Forsyth 2014; Stewart et al 2016; Stewart 2018; Thornthwaite 2018) and elsewhere (Ornstein 2012; Wragg 2015; Thorthwaite 2018). Most of the literature on social media misconduct dismissal focuses on a single jurisdiction. Further, these jurisdictions tend to be developed nations (Thorthwaite 2018).

In Australia, O'Rouke, Teicher and Pyman (2011), Thornthwaite (2013), Forsythe (2014), Corney (2014), Thorthwaite (2016) and Barnes, Balnave and Holland (2018) have analysed select social media misconduct dismissal decisions decided by decision-makers. Thorthwaite's earlier study found that in Australia, communication on social media was in the public domain (Thorthwaite 2013). In later research she identifies particular decisions that acknowledged employees' reasonable expectations of privacy when participating in social media whilst off-duty, especially when the posts are on private accounts with maximum privacy settings applied. ${ }^{12}$ Further, on the then available decisions, Thornthwaite posited that employees hold the right to voice political views, ${ }^{13}$ and to criticise employers and labour conditions on social media ${ }^{14}$ whilst they are not at work (Thorthwaite 2016 and Thorthwaite 2018).

Within the literature on social media misconduct dismissal there are studies that compare the law and decision between Global North nations, such as the examination by Ornstein (2012) of social media misuse decisions in England, France and the United States, and Mangan $(2015,2018)$ who compares decisions for social media misconduct between Canada and the United Kingdom.

A common feature of all these jurisdiction specific studies is a focus on appeal decisions of superior courts. There is a tendency to focus on identification of the state of the law within the jurisdiction, and in the comparative studies identifying common themes and difference between the identified laws of the different jurisdictions. What is not focused on are lowerlevel decision-makers dealing with social media misconduct

\footnotetext{
${ }^{6}$ Mr Scott McIntyre v Special Broadcasting Services Corporation T/A SBS Corporation [2015] FWC 6768. The sports reporter was dismissed for breaching the SBS Code of Conduct and Social Media Policy by making several inappropriate tweets about Anzac Day. A confidential out of court settlement was reached prior to the case being heard in the Federal Court of New South Wales. See generally Kampmark (2017) and Davidson (2016).

${ }^{7}$ Ward posted a Facebook comment calling the Australian flag 'racist' and was suspended. Following union action and public protest, she was reinstated and returned to work. See generally Kampmark (2017).

${ }^{8}$ The employee was dismissed by Cricket Australia for a series of tweets on her personal social media account wherein she criticised the Tasmanian Government's policies on abortion. The parties reached a confidential out of court settlement. See generally Henriques-Gomes (2018).

${ }^{9}$ Isileli "Israel" Folau v Rugby Australia Limited \& Anor, MLG2486/2019. Folau was dismissed by Rugby Australia for breaching Rugby Australia's Code of Conduct for posting a post on Twitter that said "Drunks, Homosexuals, Adulterers, Liars, Fornicators, Thieves, Atheists, Idolators: Hell Awaits You. Repent! Only Jesus Saves." On 4 December 2019, the parties reached a confidential out-of-court settlement.

${ }^{10}$ The tweet read 'Going to Africa. Hope I don't get Aids. Just kidding. I'm white!' See generally Pilkington (2013), Lucas (2013), Dimitrova, Rahmanzadeh and Lipman (2013) and Hill (2013).

${ }^{11}$ The parties reached a confidential out-of-court settlement. See generally Hytner (2019) and Robinson (2019).

${ }^{12}$ See, eg, Judith Wilkinson-Reed v Launtoy Pty Ltd T/A Launceston Toyota [2014] FWC 644 ('Wilkinson-Reed'); Ms Kim Fallens v Serco Australia Pty Ltd T/Z Serco Acacia Prison [2015] FWC 8394 ('Fallens').

${ }^{13}$ See, eg, Daniel Starr v Department of Human Services [2016] FWC 1460 [72] ('Starr').

${ }^{14}$ Mrs Robyn Vosper v Solibrooke Pty Ltd T/A Angie's Cake Emporium [2016] FWC 1168 [20] ('Vosper').
} 
dismissal at the first instance. While there is some identification and discussion of the technical nature of social media in the existing literature - particularly reflection on its uncontrolled distribution, account settings and its enduring permanence what can become lost are the cultural and economic factors leading to a contested social media misconduct dismissal.

Furthermore, what is mostly absent from the existing literature is any consideration of how social media misconduct dismissal is being treated in the Global South. Nel (2016) and Reddy (2018) in recent papers compare South African and Australian law, thereby indicating that social media misconduct dismissal is not just a legal issue in the Global North. However, like the other comparative analyses, they both narrowly focus on comparing and contrasting the state of the law rather than analysing the cultural, economic and technical milieu from which social media misconduct dismissal emanate.

This article directly responds to these gaps in the literature. It is not so concerned with the formal identification of the law as declared and applied by superior courts or reasoned argument on how the law should develop. Rather it examines the cultural, economic and technical milieu of social media misconduct dismissal matters as they are occurring in Australia and South Africa through a socio-legal structured analysis of decisions.

There is an increasing socio-legal literature that uses a structured analysis of lower-level decision-making as an insight into how social and legal factors frame and give rise to disputes. For example, Wagstaff and Tranter (2014) and Sleep and Tranter (2018) analysed review decisions by the Refugee Review Tribunal and the Administrative Appeals Tribunal (AAT) to identify how social media use is used in Australian administrative decision-making. Sleep (2019) recently examined AAT decisions of "couple-rule" matters, and decisions of the New Zealand Social Security Appeals Authority to reveal the social and legal factors involved in social security couple decisions. This approach uses the decisions as a social record rather than statements of law, through which the broader context of the dispute can be revealed and examined. A feature is the use of records and reports of lower-level decision-makers - or what is sometimes referred to as "street-level" decision-makers (Jensen 2018; Cohen 2018; Pivoras and Kaselis 2019). ${ }^{15}$ The aim is not to find the law, but the practices and contexts in which application of the law is being contested.

This method has two steps. The first is the identification of the sample of decisions from analysis through the use of a broad set of keywords and multiple searches across relevant archives and digital repositories. This identification involves a first-order of analysis in examining the found decisions to eliminate false positives. Having identified the sample, the second step is the analysis. This analysis follows established content analysis techniques of multiple readings to identify relevant themes and then extraction of material from the decisions coded according to themes. As the study in this article involved two distinct samples, Australian and South African social media misconduct dismissals, the process for identification of each sample needs to be outlined.

In Australia the sample was limited to Commonwealth level decision-making under the Fair Work Act 2009 (Cth) ${ }^{16}$ An employee who has been dismissed for social media misconduct may bring an application to challenge that decision as an "unfair dismissal" at first instance with the Fair Work Commission (FWC). ${ }^{17}$ The sample was identified through AustLII using the search terms "social media" together with the words "workplace, employment, off-duty, privacy and dismissal." The names of particular social media platforms, namely "Facebook" and "Twitter" were also used to further limit the sample to social media platforms rather than private messaging applications such as "WhatsApp," "Facebook Messenger"18 or "Snapchat."19 This resulted in 58 decisions. Assessing for false positives led to the final sample of 42 decisions. The decisions in the Australian sample are set out in Appendix 1. In addition to 36 FWC decisions, 2 were from the Federal Court of Australia, ${ }^{20} 1$ decision apiece in the Federal Circuit Court of Australia, ${ }^{21}$ the High Court of Australia, ${ }^{22}$ the Administrative Appeals Tribunal, ${ }^{23}$ and the Supreme Court of Victoria. ${ }^{24}$

The South African sample comprises written decisions of the Commission for Conciliation, Mediation and Arbitration

\footnotetext{
${ }^{15}$ The phrase "street-level" to refer to primary decision-makers has its origins in Lipsky (1980).

${ }^{16}$ Fair Work Act 2009 (Cth) s 26 which provides the referral of State power of industrial relations to the Commonwealth. All States other than Western Australia refer their Industrial Relations powers to the Commonwealth.

${ }^{17}$ Fair Work Act 2009 (Cth) s 385.

${ }^{18}$ See, eg, the case of Luke Colwell $v$ Sydney International Container Terminals Pty Ltd [2018] FWC 174 ('Colwell').

${ }^{19}$ See, eg, the case of Mr Rodney Fussell v Sydney Trains [2019] FWC 1182 ('Fussell').

${ }^{20}$ Chief of the Defence Force v Gaynor [2017] FCAFC 41 ('Gaynor FCAFC'); Gaynorv Chief of the Defence Force (No 3) [2015] FCA 1370 ('Gaynor').

${ }^{21}$ Banerji v Bowls (2013) FCAA 1052 ('Banerji').

${ }^{22}$ Comcare v Banerji [2019] HCA 23 ('Banerji HCA').

${ }^{23}$ Banerji and Comcare (Compensation) [2018] AATA 892 ('Banerji AATA').

${ }^{24}$ Jurecek $v$ Director of Transport Safety Victoria [2016] VSC 285 ('Jurecek’).
} 
(CCMA), ${ }^{25}$ and various Bargaining Council and Labour Court decisions. The sample was identified through Sabinet Legal ${ }^{26}$ using the same sample keywords as in the Australian search. This identified 161 decisions. After revision for false positives, the sample was reduced to 138 decisions. After preliminary analysis, 31 decisions were excluded as social media misconduct was not the primary focus, ${ }^{27}$ or when a decision involved a private messenger application. ${ }^{28}$ This left a sample of 97 decisions (See Appendix 2). Of the 97 cases, 85 were heard in the CCMA, 9 in industry specific Bargaining Councils, ${ }^{29}$ and 3 were matters before the Labour Court.

Both samples were then subject to a content analysis. This process involves identifying and extracting themes from the samples. Some of the material noted related to the formal legal context (such as date, the decision-maker, the legislation applicable, and whether the employee raised any rights-based defences, the final decision). Some related specifically to the technology such as the platform involved, whether privacy settings were engaged, and the actual or claimed distribution of the material. However, most of the focus was on the cultural and economic factors disclosed in the decision such as the type of work and employer, when and how the social media conduct took place, the nexus of such conduct to employment, the reason for dismissal, the form and offensiveness of the social media conduct, whether actual names were disclosed and how the employer accessed the content. Through analysis some the common themes emerged in both samples; for example, consideration of technology related factors and the concern with when and where the social media misconduct occurred. While these reflects the findings from the existing literature, an unexpected finding was the similarity between the Australian and South African samples on the ineffective use of rights-based arguments. However, very different themes also emerged; for example, the allowances of "larrikin" behaviour in the Australian sample and the strong manifestation of race in the South African sample.

\section{COMMONALITIES IN SOCIAL MEDIA MISCONDUCT IN AUSTRALIA AND SOUTH AFRICA}

This section argues that there were areas of commonality between the samples. Two commonalities had been observed in the existing literature; both relate to the socio-technical elements of social media use. The first was social media use by employers as evidence of employee misbehaviour during work or evidence of material posted by employees about their employer. The second was the low consideration given to employee's claims about ignorance of the workings of social media. The third commonality was more unexpected. Rights and rights jurisprudence is a particular feature of post-apartheid South Africa (Sarkin 1998; Dugard 2015). In contrast, Australia, especially at the Commonwealth level, has been reluctant to embrace formal rights instruments (Galligan and Morton 2006; French 2015; Kampmark 2018). From these differences it could have been expected that rights-based claims would have had more success in the South African sample than in the Australian sample. However, this was not the finding. Rather, rights-based arguments and approaches by employees were not effective in Australia and South Africa.

\subsection{SOCIAL MEDIA AS EXTENSION OF MANAGERIAL PREROGATIVE OF CONTROL/ MANIFESTATION OF WORKPLACE POWER DYNAMICS}

That social media forms an accessible, digital archive of human lives has made it a boon for entities wanting to gather information about specific persons. It has been found that social media is often used by public decision-makers to collaborate or question an applicant's entitlement to a benefit (Sleep and Tranter 2018). As has been identified in the existing literature, employers have also accessed social media as a form of extension of managerial prerogatives of control and discipline of employees' conduct while at work or over of comments by employees about their employer and employment (Du Toit 2016) even whilst "off duty."

\footnotetext{
${ }^{25}$ Whilst the decisions are final and legally binding on the parties to the dispute, they are not binding legal precedent for the Courts.

${ }^{26}$ Sabinet Legal is a fee-for-service repository of legal information at https://discover.sabinet.co.za

${ }^{27}$ See, eg, the case of FOSAWU obo Reuben Njiva v Gold Reef City Casino GAJB18743-11; Nanthus Augustus v Mass Discounters (Pty) Ltd ECPE79-15; M Paulse v Department of Health-Western Cape PSHS10-17/18.

${ }^{28}$ See, eg, the case of Mr J Ludick v Vodacom Group Ltd (operating as Vodacom) WECT16371-18.

${ }^{29}$ See, eg, Arthur Leach v Suzuki JHB South [2015] MIBC MINT 44570 D; Aubrey Mabaso v UTI South Africa (Pty) Ltd GPRFBC 35409; Dewoonarain v Prestige Car Sales (Pty) Ltd t/a Hyundai Ladysmith 20137 BALR 689 (MIBC); National Union of Metalworkers of South Africa obo Zulu / GUD Holdings (Pty) Ltd MIDB12660; M Paulse $v$ Department of Health-Western Cape PSHS10-17/18; National Union of Metalworkers of South Africa obo Victor and Warikker v Aveng Trident Steel (Pty) Ltd MEPE 1794; NEHAWU obo Obakeng Victor Tilodi v Commissioner T Ndzombane, Department of Health and Public Health \& Social Development Sectoral Bargaining Council C30/15; NUMSA obo Eugene Patterson v PFG Building Glass CHEM516-16/17; SOCRAWU obo Elroy Bibby v KSM Distributors [2018] BC PERFBC 49968; Thando Templeton Maku v Department of Social Development - Western Cape PSHS330-16/17).
} 
Consequently, both samples fulfilled expectations. In the Australian sample, 71\% (30/42) decisions and in the South African sample, 72\% (70/97) involved dismissals due to social medial evidence of misconduct at work or comments about the employer. For example, in Australia, the decisions of Mayberry, ${ }^{30}$ Connolly-Manga ${ }^{31}$ and $\mathrm{Gee}^{32}$ social media posts were used as documentary evidence of employee infractions in dismissal hearings. These infractions included being dressed as a car made of Subway branded materials behind a Subway counter, standing on top of mining machinery with its engine running, ${ }^{34}$ and taking photographs that included company assets and work infrastructure whilst working and operating company equipment respectively. ${ }^{35}$ In the South African cases of Molale ${ }^{36}$ and Mabaso, ${ }^{37}$ social media evidence of sleeping and drinking on duty was used as grounds for dismissal (Coetzee 2019). In the Australian decision of Dekort, ${ }^{38}$ and the South African decisions of Bokuva ${ }^{39}$ and $M a k u,{ }^{40}$ posts from Facebook were used by employers in evidence that employees were at social events rather than being ill as their medical certificates claimed.

In these decisions, social media was a source of evidence for employee misconduct. It was not the social media conduct per se that led to the dismissal, rather it was employees posting material of their misconduct. In these decisions social media was an archive of on job performance or misuse of leave benefits. In both circumstances it was the employee's use of social media either while at work or while they should have been at work that led to the dismissal. However, the samples reveal other ways that social media conduct could lead to dismissals.

Employees who posted disparaging comments about their employer, even when those comments were made outside of work and on private devices, were seen in both jurisdictions as a valid basis for dismissal. For example, in the Australian sample in Dover Ray ${ }^{41}$ and $O^{\prime} K_{\text {Keefe }}{ }^{42}$ employees were validly dismissed for posting off-duty disparaging remarks about their employers, even where the employer was not specifically mentioned, ${ }^{43}$ or where the disparaging comments were made whilst off-duty, on the employee's own device and with the maximum privacy settings used. ${ }^{44}$ The South African sample showed employees dismissed for making disparaging remarks about their employers on social media, for example in Andrew, ${ }^{45}$ Dietlof, ${ }^{46}$ She $^{47}$ and Madisha ${ }^{48}$. Dismissals were substantively fair where "spurious attacks" ${ }^{49}$ were "designed and succeeded in tarnishing the public image" 50 of the employer, particularly where the conduct destroyed the trust relationship making the continued employment of the employee intolerable. ${ }^{51}$ However, where there was no irretrievable breakdown of the employment relationship apparent, or no damage suffered by the employer, decision-makers held in favour of the employee

\footnotetext{
${ }^{30}$ Mayberry v Kijani Investments Pty Ltd ATF The Dawe Investments Trust Subway Wallsend T/A Subway [2011] FWA 3496 ('Mayberry').

${ }^{31}$ Naresh Connolly-Manga v Global Mining Services Pty Ltd [2019] FWC 1097 ('Connolly-Manga').

${ }^{32}$ Gee v Tasmanian Ports Corporation Pty Ltd t/a Tasports [2017] FWC 31, [36] ('Gee').

${ }^{33}$ Mayberry v Kijani Investments Pty Ltd ATF The Dawe Investments Trust Subway Wallsend T/A Subway [2011] FWA 3496, [17]-[18].

${ }^{34}$ Naresh Connolly-Manga v Global Mining Services Pty Ltd [2019] FWC 1097, [1].

${ }^{35}$ Gee v Tasmanian Ports Corporation Pty Ltd t/a Tasports [2017] FWC 31, [30].

${ }^{36}$ George Roderick Molale v Bosasa Security (Pty) Ltd [2017] CCMA GAJB27050-17 ('Molale').

${ }^{37}$ Aubrey Mabaso v UTI South Africa (Pty) Ltd GPRFBC 35409 ('Mabaso').

${ }^{38}$ Mr Antony Dekort v Johns River Tavern Pty Limited T/A Blacksmiths Inn Tavern [2010] FWA 3389 ('Dekort').

${ }^{39}$ UASA obo Siviwe Bokuva v Shoprite Checkers Ltd ECEL2040-17 ('Bokuva').

${ }^{40}$ Thando Templeton Maku v Department of Social Development - Western Cape [2017] CCMA PSHS330-16/17 ('Maku').

${ }^{41}$ Dover Ray v Real Insurance Pty Ltd [2010] FWA 8544 ('Dover Ray').

${ }^{42}$ O'Keefe v William Muir's Pty Ltd T/A Troy Williams The Good Guys [2011] FWA 5311 ('O'Keefe').

${ }^{43}$ Dover Ray $v$ Real Insurance Pty Ltd [2010] FWA 8544, [53].

${ }^{44}$ O'Keefe $v$ William Muir's Pty Ltd T/A Troy Williams The Good Guys [2011] FWA 5311, [42]-[43] ('O'Keefe').

${ }^{45}$ Stephen Devasagium Andrew v Pick n Pay Supply Chain [2014] CCMA GAJB5317-14 ('Andrew').

${ }^{46}$ CEPPWAWU obo Dietlof v Frans Loots Building Material Trust t/a Pennypinchers [2016] CCMA ECPE7247-15, [24] ('Dietlof').

${ }^{47}$ Davina Shee v Greystone Trading CC t/a Absolote Pets [2012] CCMA WECT 2852-12, [20] [22] ('Shee').

${ }^{48}$ Phillip Madisha $v$ Sandton Plant Hire (Pty) Ltd [2018] CCMA GAJB 10432-18 ('Madisha').

${ }^{49}$ CEPPWAWU obo Dietlof v Frans Loots Building Material Trust t/a Pennypinchers [2016] CCMA ECPE7247-15, [24] ('Dietlof').

${ }^{50}$ Stephen Devasagium Andrew v Pick $n$ Pay Supply Chain [2014] CCMA GAJB5317-14, [22] ('Andrew').

${ }^{51}$ CEPPWAWU obo Dietlof v Frans Loots Building Material Trust t/a Pennypinchers [2016] CCMA ECPE7247-15, [24]; Palesa Petronella Moloto v Democratic Alliance (DA) [2017] CCMA LP1723-17, [31] ('Moloto').
} 
in the South African context. ${ }^{52}$ This was also reflected in the Australian sample in Fitzgerald and Vosper. ${ }^{53}$ Furthermore, the use of social media to harass and bully other employees was a valid basis for dismissal in Australia and South Africa. In the Australian context, these include the cases of $O^{\prime} \mathrm{Keefe}^{54}$ Natoli, ${ }^{55}$ and Bowden $v$ Ottrey Homes. ${ }^{56}$ Similarly, in the South African sample, the cases of Motseme $e^{57}$ and Zulu $u^{58}$ are examples of employees levelling threatening behaviour towards fellow employees.

From the samples, it seems that Australia and South Africa are similar in the use of social media as a source of evidence of workplace infractions or misconduct. This extension of managerial prerogative of control goes from the obvious use of social media as evidence of misconduct on the job or false claims to illnesses, to social media conduct outside of work - especially when the employee posts material damaging to the employer or engages in unacceptable conduct towards another employee.

\subsection{EMPLOYEE AWARENESS OF SOCIAL MEDIA}

The second commonality between the samples was a particular reluctance by decision-makers to make allowances for the employees' understanding and technical competency in using social media. In the 2011 Australian decision of Stutsel, ${ }^{59}$ the dismissal was held to be unreasonable as the decision-maker accepted the employee's contention that he believed his racially derogatory Facebook post about his mangers were private. ${ }^{60}$ The two factors that seemed to convince the decision-makers, both at first instant and on appeal, was the employee's age and low familiarity with Facebook and that the employer did not have a social media policy. ${ }^{61}$ However, at the appeal, the Fair Work Australia Full Bench noted that "ignorance on the part of an older worker, who has enthusiastically embraced new social networking media but without fully understanding the implications of its use, might be viewed differently in the future."62 Similar allowances for an employee due to the lack of an employer social media policy was also evident in the 2012 decision of Mitchell. ${ }^{63}$

However, this latitude to employees seemed to dissipate in the Australian sample. In the 2013 decision of Little ${ }^{64}$ arguments by the employee that he did not comprehend how Facebook functioned and that the employer did not have a social media policy were brushed aside. ${ }^{65}$ Indeed, in Little the decisionmaker placed responsibility on the employee: one "hardly needs written policies or codes of conduct to understand and appreciate that...[t] he comments made...[w] ere grossly offensive and disgusting and were more than likely to cause hurt and humiliation." ${ }^{\prime 66}$ Little marked the abandonment in Australia of employees arguing that their social media competence should be a mitigating factor, reflecting a change from the earlier Stutsel decision. ${ }^{67}$ In the 2019 decision of Natoli, ${ }^{68}$ this approach can be seen as well-established and that posting inflammatory and derogatory material about another employee to social media "was just incomprehensible and foolish in the extreme" ${ }^{\text {"69 }}$ with no excuse or mitigation afforded the dismissed employee due to age, technical competence or existence or otherwise of an employer's social media policy.

\footnotetext{
${ }^{52}$ See generally Crisna Roux v SBF Services (Pty) Ltd [2017] CCMA GATW8998-17, [54]-[55] ('Roux’); SACCAWU obo Prescilla Matshidiso Motshegoa v Mass Discounters (Pty) Ltd t/a Game Stores [2015] CCMA GAJB11646-13, [15] ('Motshegoa'); Mahoro v Indube Staffing Solutions [2012] 4 BALR 395 (CCMA) [38] ('Mahoro'); Frederick Du Preez v Ster Kinekor [2011] CCMA GAJB26167-11 ('Du Preez'); FOSAWU obo Koka, Daniel v Goldreef City Casino [2011] CCMA GAJB1521511, [15] ('Koka'); Willie B Botha v Bid Air Service [2015] CCMA ECPE3142-15,[24] ('Botha').

${ }^{53}$ Fitzgerald v Smith T/A Escape Hair Design (2010) FWA 7358, [56]-[57] ('Fitzgerald'); Mrs Robyn Vosper v Solibrooke Pty Ltd T/A Angie's Cake Emporium [2016] FWC 1168 ('Vosper').

${ }^{54}$ O'Keefe v William Muir's Pty Ltd T/A Troy Williams The Good Guys [2011] FWA 5311 ('O'Keefe').

${ }^{55}$ Ms Nektaria Natoli v Anglian Community Services t/a Anglicare [2018] FWC 2180 ('Natoli').

${ }^{56}$ Bowden v Ottrey Homes - Cobram \& District Retirement Village Inc T/A Ottrey Lodge [2012] FWA 6468 ('Bowden').

${ }^{57}$ NEHAWU obo Motseme, I and 1 other $v$ Tsebo Holdings and Operations (Pty) Ltd t/a Fedics [2017] CCMA NC26-17 ('Motseme').

${ }^{58}$ National Union of Metalworkers of South Africa obo Zulu v GUD Holdings (Pty) Ltd MIDB12660 ('Zulu').

${ }^{59}$ Stutsel v Linfox Australia Pty Ltd [2011] FWA 8444 ('Stutsel').

${ }^{60}$ Stutsel v Linfox Australia Pty Ltd [2011] FWA 8444, [78] ('Stutsel').

${ }^{61}$ Stutsel v Linfox Australia Pty Ltd [2011] FWA 8444, [79] ('Stutsel'); Linfox Australia Pty Ltd v Stutsel [2012] FWAFB 7097 [33] ('Linfox').

${ }^{62}$ Linfox Australia Pty Ltd $v$ Stutsel [2012] FWAFB 7097, [34] ('Linfox').

${ }^{63}$ Mitchell v HWE Mining Pty Ltd [2012] FWA 2721, [19] ('Mitchell').

${ }^{64}$ Little v Credit Corp Group Limited T/A Credit Corp Group [2013] FWC 9642 ('Little').

${ }^{65}$ Little v Credit Corp Group Limited T/A Credit Corp Group [2013] FWC 9642, [73] ('Little').

${ }^{66}$ Little v Credit Corp Group Limited T/A Credit Corp Group [2013] FWC 9642, [69] ('Little').

${ }^{67}$ Stutsel v Linfox Australia Pty Ltd [2011] FWA 8444 ('Stutsel').

${ }^{68}$ Ms Nektaria Natoli v Anglian Community Services t/a Anglicare [2018] FWC 2180, [222] ('Natoli').

${ }^{69}$ Ms Nektaria Natoli v Anglian Community Services t/a Anglicare [2018] FWC 2180, [222] ('Natoli').
} 
What can be seen in the Australian sample is a charting of the rising ubiquity of particularly Facebook from a "few thousand [Australian] users in May 2007,"70 to approximately 18 million domestic users by September 2019 (Global Digital Report 2019). In the sample, $86 \%$ of the decisions (36/42) involve Facebook. Facebook is the most active social media platform in Australia with $91 \%$ of Australian Internet users maintaining a Facebook profile (Yellow Social Media Report 2018, p. 4) most having on average 239 "friends," (Yellow Social Media Report 2018, p. 22 ) and $62 \%$ utilising social media daily (Yellow Social Media Report 2018, p. 4). The trajectory of decisions from 2011 when novelty and newness meant that there was a degree of latitude afforded employees to the more recent "no excuse" approach reflects the growing saturation and familiarity with social media - and Facebook particularly - in Australia over the 2010s.

The South African sample tells a slightly different story. There is no decision like Stutsel. ${ }^{71}$ Rather, in South Africa employee arguments about ignorance of social media or relevant employer social media policies have been consistently unsuccessful. For example, in Mavundla and Zulu, it was assumed that employees should have realised that posting negative, derogatory or threatening comments may result in irreparable harm to the employment relationship. ${ }^{72}$ In South Africa certain conduct around showing disrespect for an employer and using racialised language - is so universally inappropriate and unacceptable that it has been repeatedly emphasised that employers do not need social media policies to adequately guide employees on appropriate conduct. ${ }^{73}$ Indeed, in Bibby, ${ }^{74}$ the "ignorance argument" ${ }^{\prime 75}$ was held to be "improbably naïve." ${ }^{76}$ Even in a decision such as Ndudzo which was contemporaneous with Stutsel, there was no allowance given to an employee who made, in comparison to the employee in Stutsel, fairly tame comments about her employer on Facebook in conversation with a friend. ${ }^{77}$ In that decision it was the "friend" who then provided the comments to the employer. This was also a pattern in South Africa that employees were still validly dismissed even when offending comments allegedly came from hacked accounts or posts made by others such as in Dlamini, ${ }^{78}$ Dagane $^{79}$ Godloza $^{80}$ Jogom $^{81}$ and Ganger ${ }^{82}$. The decision-makers have held that "the onus to protect one's account...[1] ays with the employee," ${ }^{\prime 83}$ and that the employee is responsible for their account and all the posts and responses it generates. ${ }^{84}$

It was common between Australia and South Africa that employees cannot plead mitigation based on their technical knowledge and skills in using social media, nor in the absence of an employer social media policy. However, differences can be seen. Australia came to the position over the 2010 s as social media, and especially Facebook became more ubiquitous. In South Africa, such allowances were not forthcoming even in decisions from 2010 and 2011. Indeed, the sample suggests that South Africa has a harsh workplace where employees can be fairly dismissed for mild disparaging comments about their employer such as insinuating that their employer was racist and supported xenophobia, ${ }^{85}$ or that if they were White

\footnotetext{
${ }^{70} \mathrm{http} / / /$ laurelpapworth.com/facebook-active-users-in-australia/

${ }^{71}$ Stutsel v Linfox Australia Pty Ltd [2011] FWA 8444 ('Stutsel'); Linfox Australia Pty Ltd v Stutsel [2012] FWAFB 7097 ('Linfox').

${ }^{72}$ Sithembiso Promise Mavundla v Merchants SA (Pty) Ltd a Dimension Data Company (2019) CCMA GAJB7904-19 ('Mavundla'); National Union of Metalworkers of South Africa obo Zulu / GUD Holdings (Pty) Ltd MIDB12660, [20] ('Zulu'): as this was in breach of their implied common law obligations to act in the best interests of their employer. See also National Union of Food, Beverage, Wine, Spirits and Allied Workers Union obo Arendse / Consumer Brands Business Worcester, a Division of Pioneer Foods (Pty) Ltd [2013] CCMA WECT16781-13, [37] ('Arendse'); Dagane v SSSBC and others JR 2219/14 [2018] ZALCJHB 114, [49] ('Dagane'); FAWU obo Martin Du Preez v Casidra (Pty) Ltd t/a Aanhalt Boerdery [2013] CCMA WEGE 1417-13, [26] ('Du Preez'); Daniel Rayman Nqani v Else Cole Brioche [2015] CCMA ECPE4540-15, [16] ('Nqani').

${ }^{73}$ See, eg, Happiness Harting v Container World (Pty) Ltd [2015] CCMA GAEK9537-15, [27] ('Harting'); NUMSA obo Eugene Patterson v PFG Building Glass CHEM516-16/17.

${ }^{74}$ SOCRAWU obo Elroy Bibby v KSM Distributors [2018] BC PERFBC 49968 ('Bibby').

${ }^{75}$ SOCRAWU obo Elroy Bibby v KSM Distributors [2018] BC PERFBC 49968, [43] ('Bibby').

${ }^{76}$ SOCRAWU obo Elroy Bibby v KSM Distributors [2018] BC PERFBC 49968, [42] ('Bibby').

${ }^{77}$ Moreblessing Ndudzo v Studio 05 House of Fashion [2011] CCMA GAJB28706-11 ('Ndudzo').

${ }^{78}$ NEHAWU obo Sifiso Cyril Dlamini v Dept of Social Development-Kwazulu Natal [2019] CCMA PSHS901-18/19 ('Dlamini').

${ }^{79}$ Dagane $v$ SSSBC and others JR 2219/14 [2018] ZALCJHB 114 ('Dagane').

${ }^{80}$ NUM obo Godloza, Sivuyile Yalela v Harmony Gold Mining Company Ltd [2012] CCMA FS2022-12 ('Godloza').

${ }^{81}$ NUMSA obo Ishmael Mpe Jogom v G4S Correction Services (Bloemfontein) (Pty) Ltd [2016] CCMA FSBF5052-16 ('Jogom'); see also FAWU obo Myeni, Ntokozo v Imperial Retail Solutions [2016] CCMA KNDB2662-16 [11.1] ('Myeni').

${ }^{82}$ NTM obo Ms C Ganger v Bidair Services (Pty) Ltd [2015] CCMA WECT 1273-15 ('Ganger').

${ }^{83}$ NEHAWU obo Sifiso Cyril Dlamini v Dept of Social Development-Kwazulu Natal [2019] CCMA PSHS901-18/19 ('Dlamini').

${ }^{84}$ NEHAWU obo Sifiso Cyril Dlamini v Dept of Social Development-Kwazulu Natal [2019] CCMA PSHS901-18/19, [74]; NTM obo Ms C Ganger v Bidair Services (Pty) Ltd [2015] CCMA WECT 1273-15, [20] ('Ganger').

${ }^{85}$ Daniel Rayman Nqani v Els Cole Brioche [2015] CCMA ECPE4540-15, [7]
} 
they would be treated differently. ${ }^{86}$ This is evident even when the comments were made outside work hours in contexts that the employee thought were private conversations, as was evident in Gumede ${ }^{87}$ wherein the employee stated that White people were "wicked" and that "racism is still very much alive in corporate $\mathrm{SA}^{\prime \prime}{ }^{88}$

\subsection{INEFFECTIVENESS OF RIGHTS-BASED ARGUMENTS}

The third commonality concerned the ineffectiveness of rights-based arguments in Australia and South Africa. This was both expected and unexpected. In Australia the absence of a formal rights instrument at the Commonwealth level, the piecemeal protections around privacy in the Privacy Act 1988 (Cth) and the narrow protection of political speech implied in the Commonwealth Constitution suggested that rights-based arguments by employees might have little success. In contrast, South Africa with its post-apartheid constitution and strong emphasis on a rights-based legal order might have suggested more opportunities for employees to make arguments based on rights of privacy or freedom of speech. However, the South African sample revealed otherwise.

Within the Australian sample employees regularly attempted two rights-based arguments. The first was that social media conduct, particularly when not originating on work premises or during work time, was protected by a claim to privacy. The second was that social media conduct was protected by freedom of speech.
Formal privacy protection in Australia is limited (O'Rouke, Pyman and Teicher 2007). The Commonwealth Constitution has no enshrined rights to privacy (Duvenhage 2017) or freedom of speech and only a narrowly implied constitutional freedom of communication on political matters (Pyke 2013) ${ }^{89}$ The Privacy Act 1988 (Cth) $)^{90}$ which applies to government entities and large corporations, ${ }^{91}$ concerns how private data is gathered, stored and disseminated (Thornthwaite 2018); does not establish personal rights of action for breach of privacy. There is no general right to privacy established at common law, ${ }^{92}$ nor is there a statutory cause of action for serious invasions of privacy. ${ }^{93}$ Some States do have human rights frameworks, ${ }^{94}$ which includes the right not to have one's privacy arbitrarily impeded or one's reputation attacked, ${ }^{95}$ and the freedom of expression that includes the freedom to acquire and convey information and ideas orally, in writing or in print. ${ }^{96}$ However, there were no decisions in the Australian sample where employees attempted to make arguments under the State human rights law. Also, Australia does not have social media specific privacy law (O'Rouke et al 2007; Buchbach 2017) like the European Union's General Data Protection Regulations protecting user privacy. ${ }^{97}$

Like with the employee's awareness of social media, in the Australian sample there were changes over time regarding the effectiveness of privacy-based arguments. Early (20102013) decisions ${ }^{98}$ assumed social media conduct was public (Thornthwaite 2018) and employees did not have any reasonable expectations of privacy and freedom of expression (Thornthwaite 2016). Between 2014 and 2016 there were a series of decisions, as Thornthwaite has argued, that seem to

\footnotetext{
${ }^{86}$ Happiness Harting v Container World (Pty) Ltd [2015] CCMA GAEK9537-15, [3]

${ }^{87}$ Noluthando Gumede v Mutual and Federal [2014] CCMA GAJB9817-14, [118]

${ }^{88}$ Noluthando Gumede v Mutual and Federal [2014] CCMA GAJB9817-14, [118]

${ }^{89}$ However, some States have human rights frameworks, see eg, Charter of Human Rights and Responsibilities Act 2006 (Vic) ('Human Rights Vic'); Human Rights Act 2004 (ACT) ('Human Rights ACT'); Human Rights Act 2019 (Qld) ('Human Rights Qld').

${ }^{90}$ Privacy Act 1988 (Cth) ('Privacy Act'). At a state level, see the Privacy and Personal Information Protection Act 1998 (NSW); Privacy and Data Protection Act 2014 (Vic) and the Information Privacy Act 2009 (Qld).

${ }^{91}$ Privacy Act 1988 (Cth) s 6D ('Privacy Act').

${ }^{92}$ See, eg, Victoria Park Racing and Recreation Grounds Co Ltd v Taylor (1937) 58 CLR 479 ('Victoria Park Racing'); Australian Broadcasting Corporation v Lenah Game Meats Pty Ltd (2001) HCA 63 ('Lenah Game Meats'); Kalaba v Commonwealth of Australia [2004] FCA 763 (2004) 6 ('Kalaba'). See also Van Dissel (2014), Duvenhage (2017), Thornthwaite (2018).

${ }^{93}$ Notwithstanding the Australian Law Reform Commission's recommendation for such establishment in 2014. See generally Australian Law Reform Commission, Serious Invasions of Privacy in the Digital Era Report (2014), [6.2] https://www.alrc.gov.au/publications/1-executive-summary/should-new-tort-be-enacted

${ }^{94}$ See Charter of Human Rights and Responsibilities Act 2006 (Vic); Human Rights Act 2004 (ACT); Human Rights Act 2019 (Q1d).

${ }^{95}$ Human Rights Act 2019 (Qld) s 25.

${ }^{96}$ Human Rights Act 2019 (Qld) s 21.

${ }^{97}$ Regulation (EU) 2016/679 of the European Parliament and of the Council, 27 April 2016 repealing Directive 95/46/EC.

${ }^{98}$ See, eg, Dover Ray v Real Insurance Pty Ltd [2010] FWA 8544 ('Dover Ray'); O'Keefe v William Muir's Pty Ltd T/A Troy Williams The Good Guys [2011] FWA 5311 ('O'Keefe'); Mayberry v Kijani Investments Pty Ltd ATF The Dawe Investments Trust Subway Wallsend T/A Subway [2011] FWA 3496 ('Mayberry'); Little v Credit Corp Group Limited T/A Credit Corp Group [2013] FWC 9642 ('Little').
} 
acknowledge employees' reasonable expectations of privacy, ${ }^{99}$ the right to voice political views, ${ }^{100}$ and to criticise employers and labour conditions ${ }^{101}$ whilst off-duty (Thornthwaite 2016; Thornthwaite 2018). However, post-2016 decisions suggest a reversal.

An example of the pre-2013 approach was Fitzgerald ${ }^{102}$ wherein an employee was dismissed for posting comments critical of her employer on Facebook. ${ }^{103}$ The FWC emphasised that whereas in the past complaints about employers happened in private discussions with friends "over a coffee,"104 they had become posts that can be accessed by an "uncontrollable number of people," 105 thus "no longer a private matter but public comment." ${ }^{106}$ Further, it emphasised the enduring nature of social media comments meant that regardless of when the comment was posted, it would remain public. ${ }^{107}$ Moreover, the decisionmaker noted that it was "foolish" for employees to trust that they could post on social media and have "total immunity from any consequences." ${ }^{108}$ A similar approach towards treating social media as public conduct, to which privacy arguments were not cogent, can be seen in $O^{\prime}$ Keefe,${ }^{109}$ McDiarmid, ${ }^{110}$ Bowker $^{111}$ and Pearson. $^{112}$

The decision of Wilkinson-Reed ${ }^{113}$ in 2014 suggested a reconsideration of the efficacy of privacy arguments. In that decision, communication between friends through a social media linked messaging service was regarded as analogous to a private email. ${ }^{114}$ The employer only came to know the content of the communication through accessing his ex-partner's account without her consent. ${ }^{115}$ Similarly in Fallens, an employer utilised posts originating from the employee's personal privacyprotected Facebook page as accessed from the employee's home computer as evidence of the her misconduct. ${ }^{116}$ The employer had come about the incriminating material through the actions of the employee's ex-partner ${ }^{117}$ and the FWC determined that the dismissal was invalid as the complicity of the employer in the invasion of the employer's privacy could not be condoned. ${ }^{118}$ In the 2016 decision of Vosper, ${ }^{119}$ it was suggested that employees could criticise management and their working conditions on social media when outside of work in their private time, ${ }^{120}$ despite the employer taking umbrage at the comments. ${ }^{121}$

However, in the 2016 decision of Remmert, ${ }^{122}$ the employee contested his dismissal arguing that his Facebook account was private; the post had been posted whilst he was off-duty and that the comments could only be accessed by his Facebook "friends." "123 In a return to the logic in Fitzgerald, it was held that there was a sufficient nexus between the off-duty conduct and the employment relationship, as a number of his "friends" were also employees ${ }^{124}$ and that his conduct, in a regional community, impacted the employer's reputation and legitimate business interests. ${ }^{125}$ A similar treatment for social media

${ }^{99}$ Judith Wilkinson-Reed v Launtoy Pty Ltd T/A Launceston Toyota [2014] FWC 644, [13] ('Wilkinson-Reed'); Ms Kim Fallens v Serco Australia Pty Ltd T/Z Serco Acacia Prison [2015] FWC 8394 ('Fallens').

${ }^{100}$ Daniel Starr v Department of Human Services [2016] FWC 1460 ('Starr').

${ }^{101}$ Mrs Robyn Vosper v Solibrooke Pty Ltd T/A Angie’s Cake Emporium [2016] FWC 1168, [20] ('Vosper').

${ }^{102}$ Fitzgerald $v$ Smith T/A Escape Hair Design (2010) FWA 7358 ('Fitzgerald').

${ }^{103}$ Fitzgerald v Smith T/A Escape Hair Design (2010) FWA 7358, [19] - [24] ('Fitzgerald').

${ }^{104}$ Fitzgerald v Smith T/A Escape Hair Design (2010) FWA 7358, [50].

${ }^{105}$ Fitzgerald $v$ Smith T/A Escape Hair Design (2010) FWA 7358, [50].

${ }^{106}$ Fitzgerald $v$ Smith T/A Escape Hair Design (2010) FWA 7358, [50].

${ }^{107}$ Fitzgerald $v$ Smith T/A Escape Hair Design (2010) FWA 7358, [52].

${ }^{108}$ Fitzgerald $v$ Smith T/A Escape Hair Design (2010) FWA 7358, [52] ('Fitzgerald').

${ }^{109}$ O'Keefe $v$ William Muir's Pty Ltd T/A Troy Williams The Good Guys [2011] FWA 5311 ('O'Keefe').

${ }^{110}$ McDiarmid v Commissioner of Police [2012] NSWIRComm 100.

${ }^{111}$ Sharon Bowker \& Others v DP World Melbourne Limited T/A DP World Maritime Union of Australia [2014] FWCFB 9227 ('Bowker').

${ }^{112}$ Pearson v Linfox Australia Pty Ltd (2014) FWC 446.

${ }^{113}$ Judith Wilkinson-Reed v Launtoy Pty Ltd T/A Launceston Toyota [2014] FWC 644 ('Wilkinson-Reed').

${ }^{114}$ Judith Wilkinson-Reed v Launtoy Pty Ltd T/A Launceston Toyota [2014] FWC 644, [66] ('Wilkinson-Reed').

${ }^{115}$ Judith Wilkinson-Reed v Launtoy Pty Ltd T/A Launceston Toyota [2014] FWC 644, [61] ('Wilkinson-Reed').

${ }^{116}$ Ms Kim Fallens v Serco Australia Pty Ltd T/Z Serco Acacia Prison [2015] FWC 8394, [17] - [18] ('Fallens').

${ }^{117}$ Ms Kim Fallens v Serco Australia Pty Ltd T/Z Serco Acacia Prison [2015] FWC 8394, [17] - [18] ('Fallens').

${ }^{118}$ Ms Kim Fallens v Serco Australia Pty Ltd T/Z Serco Acacia Prison [2015] FWC 8394, [20] ('Fallens').

${ }^{119}$ Mrs Robyn Vosper v Solibrooke Pty Ltd T/A Angie’s Cake Emporium [2016] FWC 1168 ('Vosper').

${ }^{120}$ Mrs Robyn Vosper v Solibrooke Pty Ltd T/A Angie's Cake Emporium [2016] FWC 1168, [20] ('Vosper').

${ }^{121}$ Mrs Robyn Vosper v Solibrooke Pty Ltd T/A Angie's Cake Emporium [2016] FWC 1168, [20] ('Vosper').

${ }^{122}$ Clint Remmert v Broken Hill Operations Pty Ltd T/A Rasp Mine [2016] FWC 6036 ('Remmert').

${ }^{123}$ Clint Remmert v Broken Hill Operations Pty Ltd T/A Rasp Mine [2016] FWC 6036, [9] ('Remmert').

${ }^{124}$ Clint Remmert v Broken Hill Operations Pty Ltd T/A Rasp Mine [2016] FWC 6036, [79] ('Remmert').

${ }^{125}$ Clint Remmert v Broken Hill Operations Pty Ltd T/A Rasp Mine [2016] FWC 6036, [79] ('Remmert'). 
misconduct on the employee's own device whilst they were not at work was taken in Colwell ${ }^{126}$ and in Waters. ${ }^{127}$ The "public" nature of Facebook was also noted in Campbell ${ }^{128}$ and in Oaky Creek Coal, ${ }^{129}$ where arguments that social media posts were private and were not relevant to the employment relationship were unsuccessful.

The decisions where employees relied on freedom of political communication as an argument against a social media misconduct dismissal also showed promise in the mid-2010s (Thornthwaite 2016; Thornthwaite 2018). These decisions applied to public service employees voicing their political opinions on social media (Buchbach 2017). In the 2013 decision of the Federal Circuit Court in Banerji, ${ }^{130}$ a public servant who, outside work hours and using her own device, anonymously tweeted critical comments regarding the government's immigration detention policies, was held to be validly dismissed in terms of the provisions of the Australian Public Service Code of Conduct. ${ }^{131}$ The employee had argued that her off-duty political speech was protected by the implied protection of political communication in the Commonwealth Constitution. This was rejected by the Federal Circuit Court which held that the constitutional freedom of political expression was not a personal right and did not provide persons with "unfettered rights of communication." ${ }^{132}$ Following dismissal, Banerji instituted a separate application for a workers' compensation claim under the Safety, Rehabilitation and Compensation $A c t^{133}$ which was rejected and she appealed to the AAT. In Re Banerji and Comcare, ${ }^{134}$ the AAT found that Banerji's dismissal "unacceptably trespassed on the implied freedom of political communication," was not lawful and did not amount to reasonable administrative action. ${ }^{135}$

In the 2016 decision of Starr, ${ }^{136}$ the disciplining of a public servant for making comments critical of social security administration outside of work was held to be wrong; suggesting a protected sphere of political speech on social media. ${ }^{137}$ Additionally, in Gaynor ${ }^{138}$ the employee was dismissed for comments critical of the Defence Force's policies regarding gay, lesbian and transgender issues made in his private social media accounts. ${ }^{139}$ He contended that his dismissal encroached upon his implied freedom of political communication. ${ }^{140}$ The Federal Court held that the "offensive" and "insulting"141 comments were a form of "political discourse"142 and the dismissal was set aside. ${ }^{143}$

However, reliance on a protected right of political speech did not endure. Gaynor was overturned on appeal to the Full Federal Court. ${ }^{144}$ The Court held that the constitutional "implied freedom" was not a personal right but rather a limit on legislative power. ${ }^{145}$ As such, Gaynor's "extreme comments" were not protected and could be evidence of serious misconduct. ${ }^{146}$ This approach was endorsed in 2019 by the High Court in the latest appeal of Banerji. ${ }^{147}$ The High Court held that the sections of the Public Service Act 1999 (Cth) that allowed for the dismissal of a public servant whose misconduct was political speech on social media were suitable, ${ }^{148}$ reasonably necessary, ${ }^{149}$ and

\footnotetext{
${ }^{126}$ Luke Colwell v Sydney International Container Terminals Pty Ltd [2018] FWC 174 ('Colwell').

${ }^{127}$ Marc Waters v Mt Arthur Coal Pty Limited T/A Mt Arthur Coal Pty Limited [2018] FWC 3285 ('Waters').

${ }^{128}$ Stephen Campbell v Qube Ports Pty Ltd T/A Qube Ports \& Bulk [2017] FWC 1211, [8] ('Campbell').

${ }^{129}$ Construction, Forestry, Mining and Energy Union v Oaky Creek Coal Pty Ltd [2017] FWC 5380 in which the Union averred their communication on the Union website was private and not in the public domain ('Oaky Creek Coal').

${ }^{130}$ Banerji v Bowls (2013) FCAA 1052 ('Banerji').

${ }^{131}$ Banerji v Bowls (2013) FCAA 1052, [104] ('Banerji').

${ }^{132}$ Banerji v Bowls (2013) FCAA 1052, [2], [4], [101] - [102], [104] - [105].

${ }^{133}$ Safety, Rehabilitation and Compensation Act 1988 (Cth).

${ }^{134}$ Banerji and Comcare [2018] AATA 892 ('Banerji AATA').

${ }^{135}$ Banerji and Comcare [2018] AATA 892, [128] ('Banerji AATA').

${ }^{136}$ Daniel Starr v Department of Human Services [2016] FWC 1460 ('Starr').

${ }^{137}$ Daniel Starr v Department of Human Services [2016] FWC 1460, [72] ('Starr').

${ }^{138}$ Gaynor v Chief of the Defence Force (No 3) [2015] FCA 1370 ('Gaynor').

${ }^{139}$ Gaynor v Chief of the Defence Force (No 3) [2015] FCA 1370, [117] - [127] ('Gaynor').

${ }^{140}$ Gaynor v Chief of the Defence Force (No 3) [2015] FCA 1370, [205] ('Gaynor').

${ }^{141}$ Gaynor v Chief of the Defence Force (No 3) [2015] FCA 1370, [247] ('Gaynor').

${ }^{142}$ Gaynor v Chief of the Defence Force (No 3) [2015] FCA 1370, [248] ('Gaynor').

${ }^{143}$ Gaynor v Chief of the Defence Force (No 3) [2015] FCA 1370, [290] ('Gaynor').

${ }^{144}$ Chief of the Defence Force v Gaynor [2017] FCAFC 41 ('Gaynor FCAFC').

${ }^{145}$ Chief of the Defence Force v Gaynor [2017] FCAFC 41 ('Gaynor FCAFC').

${ }^{146}$ Chief of the Defence Force v Gaynor [2017] FCAFC 41, [111] ('Gaynor FCAFC').

${ }^{147}$ Comcare v Banerji [2019] HCA 23 ('Banerji HCA').

${ }^{148}$ Comcare v Banerji [2019] HCA 23, [33] - [34] ('Banerji HCA').

${ }^{149}$ Comcare v Banerji [2019] HCA 23, [194] - [201] ('Banerji HCA').
} 
adequate in balance. ${ }^{150}$ Accordingly, they did not impinge upon the implied freedom of political communication and Banerji's dismissal was lawful. ${ }^{151}$

What the sample shows is that social media conduct is not protected by privacy or free speech style rights in Australia. There has been some unsteadiness in this; with a group of decisions in the mid-2010s that did allow social media conduct to be protected by privacy or an iteration of freedom of speech. However, towards the end of the decade, this trend reversed with strong statements that social media conduct is public, and employees face dismissal if their employer considered the conduct to be a breach of the employment contract. Further, there is no personal right to free speech in Australia that could protect public servants from dismissal for their social media political comments. ${ }^{152}$

In South Africa, notwithstanding numerous rights instruments, there is no reasonable expectation of privacy for an employee's social media misconduct; nor are social media comments regarded as protected by various freedom of expression rights. Unlike Australia, in South Africa the right to privacy, ${ }^{153}$ freedom of expression ${ }^{154}$ and fair labour practices ${ }^{155}$ are conferred on individuals by the Constitution of the Republic of South Africa ${ }^{156}$ and are enshrined in the Bill of Rights. ${ }^{157}$ Whilst the rights of privacy and freedom of expression are guaranteed, no right is paramount to any other, but must be balanced with other rights ${ }^{158}$ such as equality and dignity. ${ }^{159}$ Nor is any right absolute; rights may be limited (Reddy 2018). ${ }^{160}$ Moreover, privacy is also protected at common law ${ }^{161}$ and in statute by the Regulation of Interception of Communications and Provision of Communication Act. ${ }^{162}$

In the sample, South African decision-makers have consistently determined social media to be in the public or "quasi-public"163 domain, accessible by "thousands of Facebook users." ${ }^{164}$ Additionally, South African decision-makers have also emphasised the "permanent," enduring quality of social media posts that often extend beyond the control of the author, ${ }^{165}$ and that the removal of an offensive post by an employee is akin to "closing the gate of the stable once the horse has bolted."166 For example in Dladla, ${ }^{167}$ the employee's argument that Facebook posts are akin to a conversation in a "restaurant," was sharply rejected. ${ }^{168}$ Rather, the CCMA referred to the analogy of using a "megaphone in a public space."169

Further, in South Africa the non-implementation of privacy settings was a significant factor in determining the reasonable expectations of privacy in online communications. ${ }^{170}$ In the early decision of Sedick, ${ }^{171}$ that employees had not implemented privacy settings on their Facebook accounts was taken as a waiver of any rights that the employees might have had under

\footnotetext{
${ }^{150}$ Comcare v Banerji [2019] HCA 23, [202] - [206] ('Banerji HCA').

${ }^{151}$ Comcare v Banerji [2019] HCA 23, [1] ('Banerji HCA').

${ }^{152}$ Comcare v Banerji [2019] HCA 23, [135] ('Banerji HCA'); Chief of the Defence Force v Gaynor [2017] FCAFC 41, [47]-[52] ('Gaynor FCAFC').

153 Constitution of the Republic of South Africa 1996 (South Africa) ch $2 \mathrm{~s} 14$ ('Constitution RSA').

${ }^{154}$ Constitution of the Republic of South Africa 1996 (South Africa) ch 2 s 16 ('Constitution RSA').

${ }^{155}$ Constitution of the Republic of South Africa 1996 (South Africa) ch 2 s 23 ('Constitution RSA').

${ }^{156}$ Constitution of the Republic of South Africa 1996 (South Africa) ('Constitution RSA').

${ }^{157}$ Constitution of the Republic of South Africa 1996 (South Africa) ch 2 ('Constitution RSA').

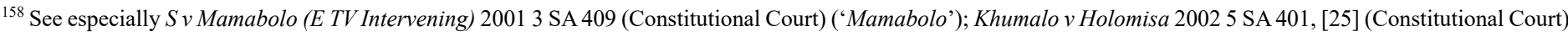
('Khumalo').

${ }^{159}$ Khumalo v Holomisa 20025 SA 401, [25] (Constitutional Court), ('Khumalo'); Le Roux v Dey 2011 3 SA 274, [34] (Constitutional Court).

${ }^{160}$ See especially the limitation clause Constitution of the Republic of South Africa 1996 (South Africa) ch $2 \mathrm{~s} 36$.

${ }^{161}$ O'Keefe v Argus Printing and Publishing Company Limited 19543 SA 244 (Constitutional Court) ('Argus Printing').

${ }^{162}$ Regulation of Interception of Communications and Provision of Communication Act 2002 (South Africa) ('RICA').

${ }^{163}$ Dagane v SSSBC and others JR 2219/14 [2018] ZALCJHB 114, [49] ('Dagane').

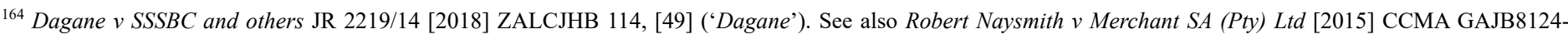

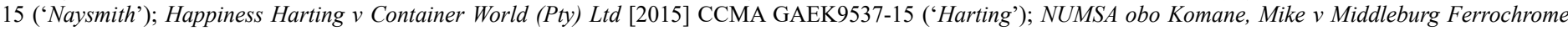
MEMP3151, [79] ('Komane’); Smit v Partners in Sexual Health (Non-profit) (2011) 32 ILJ 1470 (CCMA) ('Smit').

${ }^{165}$ Hanniker v One and Only Cape Town [2017] CCMA WECT4369-17, [63] ('Hanniker').

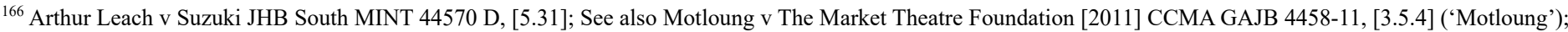
Daniel Rayman Nqani v Else Cole Brioche [2015] CCMA ECPE4540-15, [17] ('Nqani').

${ }^{167}$ Praxydis Lungile Dladla v E SAT (E.TV) [2011] CCMA GAJB948-11 ('Dladla').

${ }^{168}$ Praxydis Lungile Dladla v E SAT (E.TV) [2011] CCMA GAJB948-11, [5.2] ('Dladla').

${ }^{169}$ Praxydis Lungile Dladla v E SAT (E.TV) [2011] CCMA GAJB948-11, [5.3] ('Dladla').



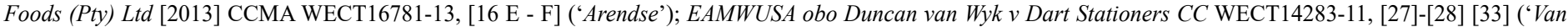
Wyk')].

${ }^{171}$ Sedick and Another v Krisray [2011] 8 BALR 879 (CCMA) ('Sedick’).
} 
the Regulation of Interception of Communications and Provision of Communication Act 2002. ${ }^{172}$ In the sample, 8 other decisions closely followed this reasoning. ${ }^{173}$ This was similar to the Australian decisions of Wilkinson-Reed ${ }^{174}$ and Fallens. ${ }^{175}$ The decision of Arendse ${ }^{176}$ also addressed that the factors of when, where and what device the employees engaged in social media misconduct was "irrelevant". ${ }^{177}$ Finally, the South African sample showed a wholly negative perception towards employees who utilise social media as a platform to express workplace grievances. ${ }^{178}$ In Beaurai, ${ }^{179}$ the decision-maker stated "[p] ublishing the allegations on the Internet was unlikely to solve the perceived problems," and was "unnecessary to publish to the international community, who could do little to help."180 Indeed, comments highly critical of employees who posted negative statements about their employers were present in $12 \%(11 / 97)$ of decisions. ${ }^{181}$

While privacy rights claims were seemingly more ineffective in South Africa than in Australia, there was a difference in how political speech-based arguments were treated. In the sample there did seem to be some tolerance of speech on social media directed towards African political leaders. In Leach, ${ }^{182}$ racially disparaging remarks about the ANC Government prior to employment was not sufficient to ground dismissal; "the applicant in reality was being punished for exercising a right that the law afforded him." ${ }^{183}$ In Cantamessa, ${ }^{184}$ posts criticising government leaders by a White employee on her Facebook account, notwithstanding the account also disclosed her employer, was likewise not sufficient: ${ }^{185}$ "the mere fact that a White person... [s]tates that President Zuma is stupid does not constitute racism." ${ }^{186}$ Although both decisions did not directly involve recourse to the right to freedom of expression as enshrined in the Bill of Rights, ${ }^{187}$ the decisions evidence a tolerance for political commentary, even if reflected through racialised lexicon that seems in contrast with the wider sample. However, this finding was not absolute.

In Msimang, $^{188}$ an African political reporter posted comments critical of the Presidency on his personal Facebook page. The decision-maker held that at the workplace, the employee had agreed to abide by the policies which limited his freedom to comment on social media, and held that the employee's Facebook posts rendered him partisan. ${ }^{189}$ That decision seems similar to the Australian position on the limitation on political

\footnotetext{
${ }^{172}$ Sedick and Another v Krisray [2011] 8 BALR 879, [52] (CCMA).

${ }^{173}$ See Fredericks v Jo Borkett Fashions [2012] 1 BALR 28 (CCMA) ('Fredricks); Jikela v Smit Amandla Marine WECT [2012] CCMA 16547-12, [61] [64] ('Jikela'); Toni Muir v Neo Africa [2012] CCMA GAJB 7546-12, [5.3] ('Muir'); Lucia Nhlapo v Delta EMD [2013] CCMA MP5131-13, [15]-[16] ('Nhlapo'); William Kerekere v Onelogix [2015] CCMA KNDB9649-15, [106] ('Nduma'); Khanya Zowia Nduma v Fowkes Brothers (Pty) Ltd [2018] CCMA WECT 5340-18, [56] ('Nduma').

${ }^{174}$ Judith Wilkinson-Reed $v$ Launtoy Pty Ltd T/A Launceston Toyota [2014] FWC 644 ('Wilkinson-Reed').

${ }^{175}$ Ms Kim Fallens v Serco Australia Pty Ltd T/Z Serco Acacia Prison [2015] FWC 8394 ('Fallens').

${ }^{176}$ National Union of Food, Beverage, Wine, Spirits and Allied Workers Union obo Arendse/ Consumer Brands Business Worcester, a Division of Pioneer Foods (Pty) Ltd [2013] CCMA WECT16781-13 ('Arendse').

${ }^{177}$ National Union of Food, Beverage, Wine, Spirits and Allied Workers Union obo Arendse/ Consumer Brands Business Worcester, a Division of Pioneer Foods (Pty) Ltd [2013] CCMA WECT16781-13, [15B] ('Arendse'). See also Noluthando Gumede v Mutual and Federal [2014] CCMA GAJB9817-14 ('Gumede'); Masemola v Commission for Conciliation, Mediation and Arbitration and Others (JR1025/2013) [2016] ZALCJHB 183; FAWU obo Ngomane, Thabiso v Radisson BLU Hotel Sandton [2018] CCMA GAJB20280-18, [8.18] ('Ngomane'); Lindokuhle Ngcobo v EOH Avanti(Pty)Ltd t/a Highveld PFS [2012] CCMA GAJB 20141-14, [14] [35]-[36] ('Ngcobo'); Iteseng Joseph Nkgwang $v$ Eskom Holdings Ltd MEMP351 ('Nkgwang'); Sithembile Portia Zulu v SATAWU [2015] CCMA MP814-15, [20] ('Portia Zulu'); Portia Ndlovu-Nzama v Ithala Development Finance Corporation [2011] CCMA KNDB11884-11, [61] ('Ndlovu-Nzama'); Daniel Rayman Nqani v Else Cole Brioche [2015] CCMA ECPE4540-15, [118] ('Nqani').

${ }^{178}$ Fredericks $v$ Jo Borkett Fashions [2012] 1 BALR 28, [6.3 H] (CCMA) ('Fredricks).

${ }^{179}$ Beaurain $v$ Martin NO and others (C16/2012)[2014] ZALCCT 16.

${ }^{180}$ Beaurain v Martin NO and others (C16/2012)[2014] ZALCCT 16, [33].

${ }^{181}$ Beaurain v Martin NO and others (C16/2012)[2014] ZALCCT 16, [33]; Media Workers Association of SA obo Mvemve and Kathorus Community Radio 2010 31 ILJ 2217 (CCMA); Portia Ndlovu-Nzama v Ithala Development Finance Corporation [2011] CCMA KNDB11884-11, [61] ('Ndlovu-Nzama'); Pamela Matiso v Nelson Mandela Tourism [2012] CCMA ECPE2825-12, [12] ('Matiso'); Amakhosi Radebe v JD Group (Pty) Ltd [2014] CCMA GAJB12297-14, [41] ('Radebe'); Mr T Mabele v SGRP Meridian (Pty) Ltd WECT: 4669- 16, [25] ('Mabele'); Ms Muthoni Kimani v Cape Peninsula University of Technology [2017] CCMA WECT 18824-17, [35] ('Kimani'); Mmakwena Martin Mokgehle v Imvula Quality Protection [2017] CCMA GAJB24628-17, [17] ('Mokgehle'); Suretha Nass v Little Green Beverages (Pty) Ltd [2017] CCMA ECEL2930-17, [40] ('Nass'); Melusi Nelson Mthabela v Arcelor Mittal SA Ltd MEKN9239 ('Mthabela').

${ }^{182}$ Arthur Leach v Suzuki JHB South MINT 44570 D ('Leach').

${ }^{183}$ Arthur Leach v Suzuki JHB South MINT 44570 D, [5.68] ('Leach').

${ }^{184}$ Cantamessa and Edcon Group (2017) 38 ILJ 1909 (CCMA) ('Cantamessa').

${ }^{185}$ Cantamessa and Edcon Group (2017) 38 ILJ 1909, [51] - [52], [57] (CCMA) ('Cantamessa'). This finding was overturned on appeal.

${ }^{186}$ Cantamessa and Edcon Group (2017) 38 ILJ 1909, [74] (CCMA) ('Cantamessa').

${ }^{187}$ Constitution of the Republic of South Africa 1996 (South Africa) ch $2 \mathrm{~s} 16$.

188 Broadcasting, Electronic, Media \& Allied Workers Union obo Msimang v South African Broadcasting Corporation KNDB14983-16 ('Msimang').

${ }^{189}$ Broadcasting, Electronic, Media \& Allied Workers Union obo Msimang v South African Broadcasting Corporation KNDB14983-16, [65] ('Msimang').
} 
communication in Gaynor ${ }^{190}$ and Banerji. ${ }^{191}$ Similar, in the recent Labour Court appeal of Cantamessa ${ }^{192}$ that overturned the first tier decision, it was held that the "[d]erogatory terms used manifested a deep-rooted racism which has no place in a democratic society. [D]ismissal was an appropriate sanction, in the circumstances." ${ }^{193}$

Something critical must be observed in the South African sample at this point. The issue of race remains central and paramount in South Africa. ${ }^{194}$ An examination of the racial dimension of the South African sample reveals striking conclusions. ${ }^{195}$ First, in 73\% (71/97) decisions where it was held that the social media misconduct dismissal was substantively fair, the employee was Black (African, Indian or Coloured), and in $54 \%$ (52/97) decisions where the misconduct was derogatory material about the employer, the employee was Black. From the sample, the South African workplace seems to be revealed as both highly racialised - with 58\% (56/97) Black employees dismissed by White employers or managers as opposed to $5 \%$ (5/97) White employees dismissed by Black employers or managers - and intolerant of (Black) employees expressing grievances or dissatisfaction in the digital realm. Yet in two decisions, racialised political comments by White employees was held to not be grounds for dismissal. At this point, the sample seems to show a particular racial lens through which both social media misconduct and the effectiveness of rightsbased arguments occur in South Africa. This finding is further pursued in the next section.

In summary, both the Australian and South African samples showed that claims by employees that their social media should be protected by a reasonable expectation of privacy have little support. Rather, social media in both countries is strongly regarded as in the public record and employees engage with social media at their own peril. Further, in Australia the sample shows a particular ineffectiveness of employee arguments that political comments were protected by rights to free speech.
While in Australia the absence of a robust formal rights framework could explain this absence, it seems more peculiar in the strong rights-based legality of South Africa. Given this strong characterisation, the decisions in Leach $^{196}$ and first tier Cantamessa ${ }^{197}$ involving White employees being unfairly dismissed for posting what was held to be "private" racialised criticism of the government seem like outliers.

\section{UNIQUE FACTORS WITH SOCIAL MEDIA MISCONDUCT IN AUSTRALIA AND SOUTH AFRICA}

The previous section focused on common findings drawn from the Australian and South African sample. In doing so, two contrasting differences began to emerge. The first was the Australian workplaces and employment law, at times, seemed to be more accommodating of employees than in South Africa where there seemed to be very little tolerance and allowances for employees. The second was a strong and enduring racial dimension to workplaces and the application of employment law in South Africa. This section focuses on these unique factors. In Australia the (slightly) more tolerant approach towards employees is further explained in relation to larrikinism. In South Africa the effect and consequences of the racialised nature of the workplace is further revealed.

\subsection{LARRIKIN CONDUCT IN AUSTRALIA}

As disclosed in the previous section, Australian decisionmakers have over the 2010s vacillated concerning allowances towards employees and their social media conduct. While there was a clear trajectory of this swinging towards employers since 2015, a factor that was evident in the sample that might explain some of the vacillation, was a degree of tolerance for "larrikin" behaviour. $17 \%$ of decisions (7/42) involved claims or allowances made for larrikin conduct. The term "larrikin" has British roots referring to "a mischievous or frolicsome

\footnotetext{
${ }^{190}$ Gaynor v Chief of the Defence Force (No 3) [2015] FCA 1370 ('Gaynor').

${ }^{191}$ Comcare v Banerji [2019] HCA 23 ('Banerji HCA').

${ }^{192}$ Edcon Limited v Cantamessa and Others (JR30/17) [2019] ZALCJHB 273.]

${ }^{193}$ Edcon Limited $v$ Cantamessa and Others (JR30/17) [2019] ZALCJHB 273 [21].

${ }^{194}$ See generally Gibson (2015).

${ }^{195}$ Determining the race of the employee and employer/manager from the texts of the decision is not an exact science. Nevertheless, we are confident with our assessment. In most decisions, the race of the players is specifically mentioned (see Samuel Mokwoane Shayi v Quality Pallets CC [2015] CCMA GAJB4751-15 where the decision states "the general manager is Junita Schultz, a coloured lady" and the employee spoke Sepedi and required an interpreter [10]. See also WOCOFO obo Siphokazi Pitseng $v$ Rayal Trading Pty Ltd [2013] CCMA GATW11253-13 where the applicant referred to Indians in her postings and Mr Khan (Assistant General Manager) and other employees were Indians who were in the employ of the respondent company [26]). In other decisions the race of the parties is obvious from the context of the matters, and particularly the form of racialised hate speech involved. For example see Dewoonarain v Prestige Car Sales (Pty) Ltd t/a Hyundai Ladysmith 20137 BALR 689 (MIBC) where the receptionist stated "Working for and with Indians is pits; they treat their own like dirt" [12]. The manager and the directors (Ronie Singh and Avi Singh) are all Indians [19] and Ahmad Mahri v Mather Dangor Financial Services GAJB15475-18 wherein the employee is specifically labelled as of the 'Muslim-faith' [14] and used derogatory terms such as the "k-word" [15]. A full list of how we identified the race of the parties in each case is available from the authors.

${ }^{196}$ Arthur Leach v Suzuki JHB South MINT 44570 D ('Leach').

${ }^{197}$ Cantamessa and Edcon Group (2017) 38 ILJ 1909 (CCMA) ('Cantamessa').
} 
youth."198 In Australia, the original pejorative denotation has moved somewhat: a larrikin is a person who is "a rough diamond,"199 or "cheeky prankster" (Bellanta 2013, p. 1) with a "lovable-scallywag air" (Bellanta 2013, p. 3) and "waggish humour" (Bellanta 2012, p. 180) who engages in "taking the mickey" of someone or something (Bellanta 2013, p. 1).

"Waggish humour" was evident in Mayberry. ${ }^{200}$ The misconduct involved the posting to Facebook a photograph of the employee clothed as a motor vehicle made from Subway branded materials ${ }^{201}$ behind a Subway counter. ${ }^{202}$ Subway summarily dismissed the employee for irreparable damaged to the employer's reputation arising from the posted image. ${ }^{203}$ The FWA found that dismissal, let alone summary dismissal, was too harsh a sanction, ${ }^{204}$ as there was "no damage to the company's name, let alone irreparable damage" ${ }^{205}$ to its reputation.

"Nonconformity, anti-authoritarianism, exceeding limits, audacity" (Vine 2009, p. 106) and apparent "careless disregard for social or political conventions" ${ }^{206}$ are further characteristics associated with Australian larrikinism. In Singh, ${ }^{207}$ an airline employee was dismissed for posting "We all support ISIS" on an Islamic extremist group's Facebook page. ${ }^{208}$ The employee argued that the post was sarcastic, and that he really did not support ISIS. $^{209}$ The FWC found that the company had failed to read the entire Facebook post that would have lead them to the conclusion that the employee was not an ISIS supporter. ${ }^{210}$ Although the FWC found that the post did not demonstrate "sarcasm" as "[i]t was not witty. It was not funny" ${ }^{211}$ but was "a ridiculous"212 and "incredibly stupid" ${ }^{213}$ post, it still held the dismissal unfair. ${ }^{214}$

A common characteristic of Australian larrikinism is "strident masculinity" (Pearl 1958, p. 8). In Renton, an employee tagged two of his work colleagues on a sexually explicit video with a statement naming them in the video and left blobs of white Sorbolene cream on his male colleague's desk. ${ }^{215}$ The employee's defence was he was "playing an annoying practical joke,"216 and that this "banter" ${ }^{217}$ was merely to "generate humour" ${ }^{218}$ done with "the intention of them having a laugh." ${ }^{219}$ While the FWC found his actions to be "boorish,"220 "crass, careless" ${ }^{221}$ and demonstrating a serious lack of sound judgement, ${ }^{222}$ it held the termination to be "harsh in that it was disproportionate to the gravity of the misconduct." 223 The sharing of a sexually explicit video that also involved body-shaming the woman with colleagues that the employee had named, following up with the "practical" joke of the Sorbolene cream, was inappropriate but not a dismissible offence. This seems to reflect an Australian acceptance of a misogynist larrikinism that objectifies and fails to see harms towards women (Manne 2017; Tomsen 2017). ${ }^{224}$

\footnotetext{
${ }^{198} \mathrm{https}: / / \mathrm{slll}$. cass.anu.edu.au/centres/andc/meanings-origins/1

${ }^{199} \mathrm{https} / / /$ slll.cass.anu.edu.au/centres/andc/meanings-origins/1

${ }^{200}$ Mayberry v Kijani Investments Pty Ltd ATF The Dawe Investments Trust Subway Wallsend T/A Subway [2011] FWA 3496 ('Mayberry').

${ }^{201}$ Mayberry v Kijani Investments Pty Ltd ATF The Dawe Investments Trust Subway Wallsend T/A Subway [2011] FWA 3496, [17] ('Mayberry').

${ }^{202}$ Mayberry v Kijani Investments Pty Ltd ATF The Dawe Investments Trust Subway Wallsend T/A Subway [2011] FWA 3496, [18] ('Mayberry').

${ }^{203}$ Mayberry v Kijani Investments Pty Ltd ATF The Dawe Investments Trust Subway Wallsend T/A Subway [2011] FWA 3496, [20] ('Mayberry').

${ }^{204}$ Mayberry v Kijani Investments Pty Ltd ATF The Dawe Investments Trust Subway Wallsend T/A Subway [2011] FWA 3496, [73] ('Mayberry').

${ }^{205}$ Mayberry v Kijani Investments Pty Ltd ATF The Dawe Investments Trust Subway Wallsend T/A Subway [2011] FWA 3496,[42], [69] ('Mayberry').

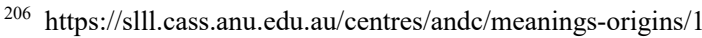

${ }^{207}$ Singh v Aerocare Flight Support Pty Ltd [2016] FWC 6186 ('Singh').

${ }^{208}$ Singh v Aerocare Flight Support Pty Ltd [2016] FWC 6186, [15] ('Singh').

${ }^{209}$ Singh v Aerocare Flight Support Pty Ltd [2016] FWC 6186, [34] ('Singh').

${ }^{210}$ Singh v Aerocare Flight Support Pty Ltd [2016] FWC 6186, [315] ('Singh').

${ }^{211}$ Singh v Aerocare Flight Support Pty Ltd [2016] FWC 6186, [318] ('Singh').

${ }^{212}$ Singh v Aerocare Flight Support Pty Ltd [2016] FWC 6186, [318] ('Singh').

${ }^{213}$ Singh v Aerocare Flight Support Pty Ltd [2016] FWC 6186, [315] ('Singh').

${ }^{214}$ Singh v Aerocare Flight Support Pty Ltd [2016] FWC 6186, [338] ('Singh').

${ }^{215}$ Renton v Bendigo HealthCare Group [2016] FWC 9089 ('Renton').

${ }^{216}$ Renton v Bendigo HealthCare Group [2016] FWC 9089, [30] ('Renton').

${ }^{217}$ Renton v Bendigo HealthCare Group [2016] FWC 9089, [13] ('Renton').

${ }^{218}$ Renton v Bendigo HealthCare Group [2016] FWC 9089, [71] ('Renton').

${ }^{219}$ Renton v Bendigo HealthCare Group [2016] FWC 9089, [7] ('Renton').

${ }^{220}$ Renton v Bendigo HealthCare Group [2016] FWC 9089, [142] ('Renton').

${ }^{221}$ Renton v Bendigo HealthCare Group [2016] FWC 9089, [117] ('Renton').

${ }^{222}$ Renton v Bendigo Health Care Group [2016] FWC 9089, [117] ('Renton').

${ }^{223}$ Renton v Bendigo HealthCare Group [2016] FWC 9089, [143] ('Renton').

${ }^{224}$ On the acceptance of a misogynist workplace conduct as humour, see Plester (2015).
} 
However, there does seem to be a line in Australia where tolerable larrikin social media conduct tips to dismissible misconduct. It seems to involve the sexualising of male bodies. In Little $^{225}$ the FWC found the dismissal lawful ${ }^{226}$ where a male employee made comments about sexual assault towards another male employee. ${ }^{227}$ The employee's arguments that the comments were humorous ${ }^{228}$ and were meant as a joke $\mathrm{e}^{229}$ where not shared by the FWC that found the comments to be acutely offensive. ${ }^{230}$ The contrast with Renton seems stark where images and text about a woman's body was not grounds for dismissal. In Fussell, ${ }^{231}$ the FWC held that the forwarding by a male employee of an image of his erect penis to a female colleague was at the "extreme outer limit of offensiveness," 232 and the reason for dismissal was valid. ${ }^{233}$ In the sample, the limit to tolerable larrikin conduct seemed to be the sexualised male body. ${ }^{234}$

It also seems to be the male body in danger. In Naresh, ${ }^{235}$ an employee was dismissed for posting a "cool as hell" 236 image of himself standing on top of a mining machine, 1.6 metres above the ground with its engine running. ${ }^{237}$ The FWC upheld the dismissal partly as the image was evidence of unsafe work practices, ${ }^{238}$ but particularly as evidence of the brazen disregard for workplace health and safety and the serious risk to the employer's reputation and profitability if seen by its clients. ${ }^{239}$

The sample shows that while larrikin conduct through social media is tolerated to a degree in Australia; there are limits, seemingly around the representing of the male body. Indeed, in the Australian sample, in 4/42 decisions the employee had explained their social media conduct using the term 'joke.' In South Africa, 'joke' was only used by an employee as an explanation in a single decision. ${ }^{240}$ While not all Australians who argued that their social media misconduct should be understood and excused as larrikin carrying-on were successful, 72\% (5/7) cases were. This finding coalescences with the broader finding emerging from comparing the samples, that the balance in Australian workplaces and employment law is slightly more towards employees. However, this comes with a caveat that this only extends to employees manifesting Australian hegemonic masculine values of "taking the piss" and misogyny (Bellanta 2012, p. 180).

\subsection{RACIALISED HATE SPEECH IN SOUTH AFRICA}

As was suggested in the findings in the previous section, race is a fundamental factor in South Africa. Indeed, the sample strongly shows that regardless of the Constitutional imperatives of equality entrenched in the Bill of Rights, ${ }^{241}$ the employment equity $^{242}$ and affirmative action measures ${ }^{243}$ instituted to eradicate and redress past inequalities and unfair discrimination within the labour force, South Africa remains a deeply divided society. It is a nation still contending with the divisive colonial and apartheid legacies (Potgieter and Moosa 2018) and deep-seated hurt, biases, and prejudices (Gibson 2015) and this was strongly evident in the sample of social media misconduct decisions. ${ }^{244}$

"Hate speech" can be defined as "the use of abusive, racist and disparaging comments, words or phrases directed against particular race, religion, ethnic background, gender or sexual preference" (Cassim 2015, p. 309; Van der Merwe et al 2008, p. 444) and is expressly excluded from the general right to freedom of expression under s 16 of the Constitution of the Republic of

\footnotetext{
${ }^{225}$ Little v Credit Corp Group Limited T/A Credit Corp Group [2013] FWC 9642 ('Little').

${ }^{226}$ Little v Credit Corp Group Limited T/A Credit Corp Group [2013] FWC 9642, [84] ('Little').

${ }^{227}$ Little v Credit Corp Group Limited T/A Credit Corp Group [2013] FWC 9642, [11] ('Little').

${ }^{228}$ Little v Credit Corp Group Limited T/A Credit Corp Group [2013] FWC 9642, [45] ('Little').

${ }^{229}$ Little v Credit Corp Group Limited T/A Credit Corp Group [2013] FWC 9642, [49] ('Little').

${ }^{230}$ Little v Credit Corp Group Limited T/A Credit Corp Group [2013] FWC 9642, [77] ('Little').

${ }^{231}$ Mr Rodney Fussell v Sydney Trains [2019] FWC 1182 ('Fussell').

${ }^{232}$ Mr Rodney Fussell v Sydney Trains [2019] FWC 1182, [135] ('Fussell').

${ }^{233}$ Mr Rodney Fussell v Sydney Trains [2019] FWC 1182, [110] ('Fussell').

${ }^{234} \mathrm{On}$ the relation between larrikinism and the male body as a site of sexual violence, see Arnold (2020).

${ }^{235}$ Naresh Connolly-Manga v Global Mining Services Pty Ltd [2019] FWC 1097 ('Connolly-Manga').

${ }^{236}$ Naresh Connolly-Manga v Global Mining Services Pty Ltd [2019] FWC 1097, [1] ('Connolly-Manga').

${ }^{237}$ Naresh Connolly-Manga v Global Mining Services Pty Ltd [2019] FWC 1097, [1] ('Connolly-Manga').

${ }^{238}$ Naresh Connolly-Manga v Global Mining Services Pty Ltd [2019] FWC 1097, [62] ('Connolly-Manga').

${ }^{239}$ Naresh Connolly-Manga v Global Mining Services Pty Ltd [2019] FWC 1097, [37] ('Connolly-Manga').

${ }^{240}$ National Union of Metalworkers of South Africa obo Zulu / GUD Holdings (Pty) Ltd MIDB12660, [22] ('Zulu').

${ }^{241}$ Constitution of the Republic of South Africa 1996 (South Africa) ch 2 s 9.

${ }^{242}$ Employment Equity Act 55 of 1998 ('Equity Act').

${ }^{243}$ Skills Development Act 97 of 1998 ('Skills Act'); Broad-Based Black Economic Empowerment Act 53 of 2003 ('Empowerment Act').

${ }^{244}$ See also Cassim (2015); Shaw (2011); Van der Merwe et al (2008).
} 
South Africa, ${ }^{245}$ and is prohibited in terms of the Promotion of Equality and the Prevention of Unfair Discrimination Act. ${ }^{246}$ In the sample, decision-makers have been unambiguous in condemning racist hate speech in the workplace, irrespective of whether the conduct occurs on or off-duty, in person or online. ${ }^{247}$ The 'k-word' is the worst insult that can be brought to bear on Black persons "as it runs against the very essence of our constitutional ethos or quintessence." ${ }^{248}$ Likewise, "boer" has been held, when spoken by a Black person towards a White individual to be as offensive as the "k-word."249

In 59\% (57/97) of the sample, social media hate speech was the primary reason for dismissal. Within these decisions, there were four categories of racialised disputes. Race is a legal and political concept in South Africa in employment equity 250 and economic empowerment legislation ${ }^{251}$ namely African, ${ }^{252}$ Coloured ${ }^{253}$ and Indian ${ }^{254}$ which together constitute 'Black people' and Whites. ${ }^{255}$ Of the 57 decisions, 53\% (30/57) where
African employees vilifying White individuals, followed by $9 \%$ (5/57) of vilification by White employees towards Black people, and 7\% (4/57) Coloured employees using hate speech against White employers. The remaining cases included intra-racial hate speech, ${ }^{256}$ xenophobic vilification, ${ }^{257}$ and hate speech between Black people. ${ }^{258}$ In Dagane ${ }^{259}$ social media posts by an African police officer that he hated Whites and threatened genocide upon them ${ }^{260}$ constituted "hate speech," ${ }^{261}$ and was deemed a fair reason for dismissal. ${ }^{262} \mathrm{~A}$ similar treatment for racial slurs inciting Black individuals to kill White persons, ${ }^{263}$ to "drive whites back to the sea ...because Africa belongs to blacks,"264 and the promotion of genocide ${ }^{265}$ was held in $\mathrm{Ngcobo}^{266}$ and Booi. ${ }^{267}$ Black African employees were fairly dismissed for calling Whites people "wicked,"268 "shit pig skins,"269 "snakes and idiots," 270 and "inja". ${ }^{271} \mathrm{~A}$ similar level of intolerance by Coloured employees posting about their White employers was also evident in the sample. In Du Preez, ${ }^{272}$ a Coloured employee

${ }^{245}$ Constitution of the Republic of South Africa 1996 (South Africa) ch 2 s 16(2)(c).

${ }^{246}$ Promotion of Equality and the Prevention of Unfair Discrimination Act 4 of $2000 \mathrm{~s} 10$.

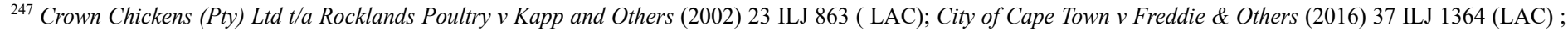


and Arbitration and Others (2017) 38 ILJ 97, [4] (CC) ('SARS').

${ }^{248}$ South African Revenue Service v Commission for Conciliation, Mediation and Arbitration and Others (2017) 38 ILJ 97 (CC) ('SARS').

${ }^{249}$ Makhanya v St Gobain [2019] 7 BALR 720 (NBCCI).

${ }^{250}$ Employment Equity Act 55 of 1998 ch 1 s 1 ('Equity Act').

${ }^{251}$ Broad-Based Black Economic Empowerment Act 53 of 2003 s 1 ('Empowerment Act').

${ }^{252}$ Makes up $80.7 \%$ of the current population: http://www.statssa.gov.za/publications/P0302/P03022019.pdf

${ }^{253}$ Makes up $8.8 \%$ of the current population: http://www.statssa.gov.za/publications/P0302/P03022019.pdf

${ }^{254}$ Makes up 2.4\% of the current population: http://www.statssa.gov.za/publications/P0302/P03022019.pdf

${ }^{255}$ Makes up 7.9\% of the current population: http://www.statssa.gov.za/publications/P0302/P03022019.pdf

${ }^{256}$ See eg, Dewoonarain v Prestige Car Sales (Pty) Ltd t/a Hyundai Ladysmith 20137 BALR 689 (MIBC) ('Dewoonarain').

${ }^{257}$ See, eg, WOCOFO obo Siphokazi Pitseng v Rayal Trading Pty Ltd [2013] CCMA GATW11253-13.

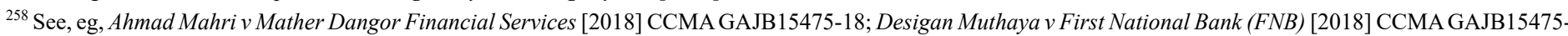
18; Samuel Mokwoane Shayi v Quality Pallets CC [2015] CCMA GAJB4751-15; Lindiwe Sweetness Shozi v Standard Bank [2017] CCMA KNDB6956-17.

${ }^{259}$ Dagane $v$ SSSBC and others JR 2219/14 [2018] ZALCJHB 114 ('Dagane’).

${ }^{260}$ Dagane v SSSBC and others JR 2219/14 [2018] ZALCJHB 114, [1] ('Dagane’).

${ }^{261}$ Dagane v SSSBC and others JR 2219/14 [2018] ZALCJHB 114, [49] ('Dagane’).

${ }^{262}$ Dagane v SSSBC and others JR 2219/14 [2018] ZALCJHB 114, [49] ('Dagane’).

${ }^{263}$ Lindokuhle Ngcobo v EOH Avanti(Pty)Ltd t/a Highveld PFS [2012] CCMA GAJB 20141-14, [12] ('Ngcobo').

${ }^{264}$ Booi v Wonderstone [2013] CCMA NWKD963-13, [15] ('Booi’).

${ }^{265}$ Lindokuhle Ngcobo v EOH Avanti(Pty)Ltd t/a Highveld PFS [2012] CCMA GAJB 20141-14, [7] ('Ngcobo').

${ }^{266}$ Lindokuhle Ngcobo v EOH Avanti(Pty)Ltd t/a Highveld PFS [2012] CCMA GAJB 20141-14, [7] ('Ngcobo').

${ }^{267}$ Booi v Wonderstone [2013] CCMA NWKD963-13 ('Booi').

${ }^{268}$ Noluthando Gumede v Mutual and Federal [2014] CCMA GAJB9817-14, [118] ('Gumede’).

${ }^{269}$ Mandla Zamokwakhe Magubane v De Heus [2017] CCMA KNPM2101-17, [5.4] ('Magubane’).

270 Jikela $v$ Smit Amandla Marine WECT [2012] CCMA 16547-12, [8] ('Jikela').



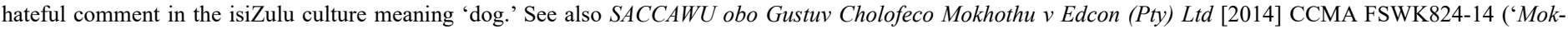

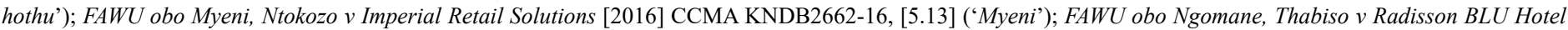
Sandton [2018] CCMA GAJB20280-18, [8.18] ('Ngomane'); Mandla Zamokwakhe Magubane v De Heus [2017] CCMA KNPM2101-17, [5.4] ('Magubane').

${ }^{272}$ FAWU obo Martin Du Preez v Casidra (Pty) Ltd t/a Aanhalt Boerdery [2013] CCMA WEGE 1417-13 ('Du Preez'). 
was fairly dismissed for the Facebook posts "kill the boer, kill the farmer." ${ }^{273}$ In Motloung ${ }^{274}$ the constitutional right to free speech as a defence for social media hate speech was expressly rejected. ${ }^{275}$ This sentiment that freedom of speech does not protect hate speech by employees was also specifically noted in $14 \%(8 / 57)$ of the decisions. ${ }^{276}$

The extent of intolerance to racialised talk on social media can be seen in Nqani, ${ }^{277}$ where an African employee was fairly dismissed for posting that his White employer was xenophobic and racist on Facebook. ${ }^{278}$ However, there were three decisions (3/30) $10 \%$ where a Black employee was successful in arguing the dismissal for social media racial hate speech about White individuals was unfair. For example in $\mathrm{Maja}^{279}$ the dismissal was not fair as the racism on the employee's "[Facebook] profile does not exhibit a connection with the employer." ${ }^{280}$ Likewise, in Ndhlovu, ${ }^{281}$ comments demanding "boers" to leave South Africa ${ }^{282}$ was not sufficient to justify a fair dismissal. ${ }^{283}$ In Nkala, ${ }^{284}$ the employee was dismissed for posting the statement "until we learn to unlearn killing each other and learn how to kill these white rednecks or any of the racist pigs, then we will be respected" on Facebook. ${ }^{285}$ The employees who felt aggrieved by the statement were largely White. ${ }^{286}$ The decision-maker found that the employer had acted inconsistently by not dismissing two White employees who had also made racial comments ${ }^{287}$ thereby indicating that the employer overlooked and tolerated racism in the workplace. ${ }^{288}$ Significantly, the decision-maker noted that the Black employee's "[W]hite colleagues got away with very serious allegations of racist remarks," ${ }^{289}$ and found the employee's dismissal substantively unfair due to the inconsistent application of discipline and policies. ${ }^{290}$

In the 9\% (5/57) of decisions where a White employee engaged in social media hate speech towards Black people, in $60 \%(3 / 5)$ it was held that the dismissal was fair. In Haviga, ${ }^{291}$ comments posted by a White employee towards African women stating that "half the women [in South African townships] are overweight and the other half are HIV infected," ${ }^{292}$ warranted dismissal. ${ }^{293}$ In that decision, the employee's Constitutional right of freedom of expression was reasonably limited by the need to protect others' rights to dignity. ${ }^{294}$ Similarly, in Bird ${ }^{295}$ dismissal of a White employee for posting a picture of the old

${ }^{273}$ FAWU obo Martin Du Preez v Casidra (Pty) Ltd t/a Aanhalt Boerdery [2013] CCMA WEGE 1417-13, [11] ('Du Preez'). See also National Union of Food, Beverage, Wine, Spirits and Allied Workers Union obo Arendse / Consumer Brands Business Worcester, a Division of Pioneer Foods (Pty) Ltd [2013] CCMA WECT16781-13 ('Arendse'); MATUSA obo Paulse v JD Kirsten Boedery (Pty) Ltd WECT17777-18 ('Paulse'); EAMWUSA obo Duncan van Wyk v Dart Stationers CC WECT14283-11 ('Van Wyk').

${ }^{274}$ Motloung $v$ The Market Theatre Foundation [2011] CCMA GAJB 4458-11 ('Motloung').

${ }^{275}$ Motloung v The Market Theatre Foundation [2011] CCMA GAJB 4458-11, [4.4] ('Motloung').

${ }^{276}$ Daniel Rayman Nqani v Else Cole Brioche [2015] CCMA ECPE4540-15, [17] ('Nqani'); Lucienne- Anne Haviga v SAA (SOC) Ltd [2014] CCMA GAEK7750-14, [32] ('Haviga'); Kenneth Marshall Alexander v Ebesa Architects (Pty) Ltd [2015] CCMA WECT19446-15 ('Alexander'); NASUWU obo Ngxwana v M Red Alert Cleaning and Security [2016] CCMA ECEL4931-16, [32.5] ('Ngxwana'); Broadcasting, Electronic, Media \& Allied Workers Union obo Msimang v South African Broadcasting Corporation KNDB14983-16, [49] ('Msimang'); SACCAWU obo Gustuv Cholofeco Mokhothu v Edcon (Pty) Ltd [2014] CCMA FSWK824-14, [29] ('Mokhothu'); Johannes Makganthe Ngoepe v Quemic (Pty) Ltd [2015] CCMA GAJB4016-15, [25] ('Ngoepe') ; Dewoonarain v Prestige Car Sales (Pty) Ltd t/a Hyundai Ladysmith 20137 BALR 689 (MIBC) ('Dewoonarain').

${ }^{277}$ Daniel Rayman Nqani $v$ Else Cole Brioche [2015] CCMA ECPE4540-15, [17] ('Nqani').

${ }^{278}$ Daniel Rayman Nqani $v$ Else Cole Brioche [2015] CCMA ECPE4540-15, [18] [26] ('Nqani'). See also Happiness Harting v Container World (Pty) Ltd [2015] CCMA GAEK9537-15, [31] ('Harting'); NUM obo Godloza, Sivuyile Yalela v Harmony Gold Mining Company Ltd [2012] CCMA FS2022-12 ('Godloza'); NEHAWU obo Obakeng Victor Tilodi v Commissioner T Ndzombane, Department of Health and Public Health \& Social Development Sectoral Bargaining Council C30/15 ('Tilodi'); SATAWU obo of B. Sam and Two Others v Ikhethele Terminal Services (Pty) Limited [2012] CCMA WECT12982-12 ('Sam').

${ }^{279}$ Pontsho Maja v Glencore Lion Smelter [2016] CCMA LP3649-16 ('Maja').

${ }^{280}$ Pontsho Maja v Glencore Lion Smelter [2016] CCMA LP3649-16, [64] ('Maja').

${ }^{281}$ Mafabatho Ndhlovu v Adve Tech Copperleaf College [2018] CCMA GATW 12969-18 ('Ndhlovu').

${ }^{282}$ Mafabatho Ndhlovu v Adve Tech Copperleaf College [2018] CCMA GATW 12969-18, [11] ('Ndhlovu').

${ }^{283}$ Mafabatho Ndhlovu v Adve Tech Copperleaf College [2018] CCMA GATW 12969-18, [21] ('Ndhlovu').

${ }^{284}$ SACWU obo Nkala Sipho v Sasol Synfuels [2017] MPCHEM355-15/16 ('Nkala').

${ }^{285}$ SACWU obo Nkala Sipho v Sasol Synfuels [2017] MPCHEM355-15/16, [6] ('Nkala').

${ }^{286}$ SACWU obo Nkala Sipho v Sasol Synfuels [2017] MPCHEM355-15/16, [13] ('Nkala').

${ }^{287}$ SACWU obo Nkala Sipho v Sasol Synfuels [2017] MPCHEM355-15/16, [38] ('Nkala').

${ }^{288}$ SACWU obo Nkala Sipho v Sasol Synfuels [2017] MPCHEM355-15/16, [42] ('Nkala').

${ }^{289}$ SACWU obo Nkala Sipho v Sasol Synfuels [2017] MPCHEM355-15/16, [42] ('Nkala').

${ }^{290}$ SACWU obo Nkala Sipho v Sasol Synfuels [2017] MPCHEM355-15/16, [43] ('Nkala').

${ }^{291}$ Lucienne- Anne Haviga v SAA (SOC) Ltd [2014] CCMA GAEK7750-14 ('Haviga').

${ }^{292}$ Lucienne- Anne Haviga v SAA (SOC) Ltd [2014] CCMA GAEK7750-14, [6] ('Haviga').

${ }^{293}$ Lucienne- Anne Haviga v SAA (SOC) Ltd [2014] CCMA GAEK7750-14, [39] ('Haviga').

${ }^{294}$ Lucienne- Anne Haviga v SAA (SOC) Ltd [2014] CCMA GAEK7750-14, [32] ('Haviga').

${ }^{295}$ Anthony Mark Bird v Rand Mutual Admin Services (Pty) Ltd [2018] CCMA GAJB15348-17 ('Bird'). 
apartheid era South African flag with the words "Good South Africa" ${ }^{296}$ was held to be a "symbol of white supremacy over the black majority ... [t] hat were oppressed during the apartheid era under this flag," ${ }^{297}$ and was deemed substantively fair. ${ }^{298}$ However, these decisions should be contrasted with Leach ${ }^{299}$ and first tier Cantamessa ${ }^{300}$ that were discussed in the previous section where at first instance the dismissal of White employees for racialised political comments was held to be unfair. In $40 \%(2 / 5)$ of the small number of decisions concerning a White employee and hate speech, the employee was successful through convincing the decision-maker that the comments were primarily political and not racist in motivation.

The sample shows South Africa is a society in which race and race conflict is at the forefront. At one level, the response of decision-makers could be commended. In Roose, ${ }^{301}$ the decisionmaker noted that "[r]acism is a cancer in the country...[i]ts wider impact on employees and consequent disharmony in the workplace renders it unacceptable" 302 and generally, the sample shows very little tolerance for employees engaging in racialised hate speech. However, the broader social and economic context of South Africa should be considered. Within the South African sample, in $86 \%$ (83/97) overall and $60 \%$ (34/57) of the hate speech decisions involved Black employees. In 5\% (5/97) of the sample, the manager or employer was Black, and the dismissed employee was White.

South African has a long history of racialised discrimination and inequality, particularly in economic and employment relations (Potgieter and Moosa 2018). Prior to the apartheid regime, the majority of the African communities were divested of their land and resources and subjugated into a position of subservience to a White minority (Magubane 1986). This stark division intensified during the apartheid regime where the racialised workplace of White employers and Black employees was characterised by "deeply-rooted adversarialism," fuelled by "unjust, repressive" laws and policies (Du Toit 2006). Linked to this, the apartheid "Bantu" education that only prepared Black students for menial and low-skilled work effectively excluding, along with direct prohibitions, Black people from securing high-skilled status and remunerated employment. ${ }^{303}$ This resulted in a small, elite class of White skilled workers, and a largely unskilled Black population (Potgieter and Moosa 2018). Notwithstanding democratic elections in 1994, the formation of South Africa's first Black-majority government and the passage of laws and policies to address employment equity, "white monopoly capital" persists, and employment relations still predominately involves White ownership and White top management with Black employees and a largely Black African skilled, semi-skilled and unskilled labour market. ${ }^{304}$

Indeed, the economic legacy of apartheid seemingly endures (Potgieter and Moosa 2018). In 2019, World Bank figures have $55.5 \%$ of all South Africans living below the upper-bound poverty level, ${ }^{305}$ with unemployment at $29 \%{ }^{306}$ This inequality renders South Africa a highly divided nation. Institute for Justice and Reconciliation 2017 figures indicated that 30.4\% of South Africans distrust people from other races, and $27.4 \%$ distrust people with different religious affiliations. While $38 \%$ of the South Africans stated that they did not have any difficulty with other race groups, and $66.3 \%$ of White people indicating that they did not have any problems associating with any other race group, $26.9 \%$ of Black people noted that they found it most difficult to associate with White individuals. ${ }^{307}$

\footnotetext{
${ }^{296}$ Anthony Mark Bird v Rand Mutual Admin Services (Pty) Ltd [2018] CCMA GAJB15348-17, [13] ('Bird').

${ }^{297}$ Anthony Mark Bird v Rand Mutual Admin Services (Pty) Ltd [2018] CCMA GAJB15348-17, [53] ('Bird').

${ }^{298}$ Anthony Mark Bird v Rand Mutual Admin Services (Pty) Ltd [2018] CCMA GAJB15348-17, [53] ('Bird'). See especially Jolanda Roose v Netcare 911 [2016] CCMA ECPE405-16, [18] wherein a racist, derogatory comment warranted dismissal even for a first transgression ('Roose').

${ }^{299}$ Arthur Leach v Suzuki JHB South MINT 44570 D ('Leach').

${ }^{300}$ Cantamessa and Edcon Group (2017) 38 ILJ 1909 (CCMA) ('Cantamessa').

${ }^{301}$ Jolanda Roose $v$ Netcare 911 [2016] CCMA ECPE405-16 ('Roos').

302 Jolanda Roose v Netcare 911 [2016] CCMA ECPE405-16, [70] ('Roos').

${ }^{303} \mathrm{http}: / /$ www.saha.org.za/youth/the future is ours.htm

${ }^{304}$ Employment Equity Act 55 of 1998 ('Equity Act'); Skills Development Act 97 of 1998 ('Skills Act'); Broad-Based Black Economic Empowerment Act 53 of 2003 ('Empowerment Act'). See generally the 19th Commission of Employment Equity Annual Report 2018-2019 at https://www.labourguide.co.za/workshop/1692-19th-cee-annualreport/file which noted $65.5 \%$ of top management positions were still occupied by White people (p. 20). Black African employees constitute $63.3 \%$ of skilled employees (p. 34), 75.5\% of semi-skilled employees (p. 38) and $83.7 \%$ of the unskilled workforce (p. 42). "White monopoly capital" refers to the White population's pervasive control over the South African economy - see, eg, Anwar 2017 for a general discussion. According to the Broad-Based Black Economic Empowerment Commission's annual report on National Status and Trends Transformation (2018), Black ownership of the JSE's listed entities was 25.2\% (p.51) at https://www.bbbeecommission.co.za/wpcontent/uploads/2019/06/National-Status-Trends-on-Black-Economic-Empowerment-Report-31-March-2019-Approved-FINAL.pdf.

${ }^{305} \mathrm{https} / / /$ databank.worldbank.org/data/download/poverty/33EF03BB-9722-4AE2-ABC7-AA2972D68AFE/Global_POVEQ_ZAF.pdf See also http://www.statssa.gov. za/publications/P03101/P031012019.pdf

${ }^{306}$ Roughly 6.7 million individuals: http://www.statssa.gov.za/?page_id=737\&id=1>

${ }^{307}$ http://www.ijr.org.za/home/wp-content/uploads/2018/03/IJR-Barometer-Report-2017-WEB-final.pdf
} 
Investigating interpersonal trust within the workplace, the Institute for Justice and Reconciliation found that White persons exhibit the highest level of trust towards colleagues, whilst Black African employees exhibit the lowest levels. ${ }^{308}$ Almost 21\% of respondents indicated that they experienced racism in the workplace in their daily lives "always" or "often," with $41.8 \%$ of employees agreeing that it is most difficult to confront racism by superiors at work. ${ }^{309}$

In an economy that is highly racially stratified, where the legacy of apartheid remains a lived reality especially for Black South Africans, it is unsurprising that racialised comments are shared on social media. It is also unsurprising that South African workplaces are a catalyst for these comments given the enduring fractured relations between Black and White people. In this context, White employers or White management dismissing Black employees for their social media conduct can be seen as less about upholding rights of freedom from racial vilification above freedom of speech, but more a strategy of control against a Black workforce. Indeed, the sample suggests that social media misconduct dismissal in South Africa is another forum for the continuance of White privilege.

\section{CONCLUSION}

This article has argued, through an analysis of a sample of 42 Australian and 97 South Africa social media misconduct dismissal decisions, that the enduring and uncontrolled audience of social media combined with national specific factors influence how decision-makers decide social media misconduct matters. Addressing a need for more comparative work that include consideration of digital diffusion and disruption in the Global South, predominately "street-level" decisions from Australia and South Africa were analysed to identify the cultural, economic and technological factors driving contested social media misconduct dismissals. Three commonalities were identified: social media content as evidence of "at work" misconduct; reluctance to allow employees to claim ignorance of the nature of social media; and the ineffectiveness of rights-based arguments. While this finding was unsurprising in Australia given the absence of a formal rights instrument. Two unique factors were also identified; in Australia there was a degree tolerance for larrikin behaviour, while in South Africa the racial divisions and racial impact of social media misconduct dismissals was highly significant and visible.

In Australia, the absence of entrenched political rights means that employee social media use is not subject to reasonable expectations of privacy. However, there is also tolerance for a certain level of larrikin behaviour. In South Africa, the existence of enshrined rights manifests differently in the context of social media misconduct dismissal.

\section{REFERENCES}

1. Anderson, G., Brodie, D., and Riley, J. 2017. The Common Law Employment Relationship: A Comparative Study. Cheltenham, UK: Edward Elgar Publishing Limited.

2. Anwar, Mohammed Amir. 2017. "White people in South Africa still hold the lion's share of all forms of capital." The Conversation. https://theconversation.com/whitepeople-in-south-africa-still-hold-the-lions-share-of-allforms-of-capital-75510.

3. Arnold, B. 2020. "Eyes Wide Shut: Homosociality, Justice and Male Rape through an Australian Lens." In K. Weinert, K. Crawley and K. Tranter (eds.) Law, Lawyers and Justice: Through Australian Lenses. London, UK: Routledge.

4. Australian Law Reform Commission, Serious Invasions of Privacy in the Digital Era (Report No 123, 2014). https:// www.alrc.gov.au/publication/serious-invasions-of-privacyin-the-digital-era-alrc-report-123/ Accessed 29/03/2020.

5. Banghart, S., Etter, M., and Stohl, C. 2018. "Organizational Boundary Regulation Through Social Media Policies." Management Communication Quarterly, 32 (3): 337- 378.

6. Barnes, A., Balnave, N., and Holland, P. 2018. "Utterly Disgraceful": Social Media and The Workplace." Australian Journal of Public Administration, 77 (3): 492- 499.

7. Bellanta, M. 2012. Larrikins: A History. St Lucia, Qld: University of Queensland Press.

8. Broad-Based Black Economic Empowerment Commission, National Status and Trends Transformation 2018 (Wed page) https://www.bbbeecommission.co.za/ wp-content/uploads/2019/06/National-Status-Trendson-Black-Economic-Empowerment-Report-31-March2019-Approved-FINAL.pdf.

9. Bellanta, M. 2013. “The Leary Larrikin.” Ozwords, 22 (1): 1-3.

10. Brown, D., Roberson, T., and Sullivan, L. 2012. "I see what you did there: The use of social networks to gather evidence." Southern Law Journal, 22 (2): 241- 267.

11. Buchbach, J. 2017. Social Media Policies and Work: Reconciling Personal Autonomy Interests and Employer Risks. Ph.D. thesis, Queensland University of Technology, Brisbane.

12. Cassim, F. 2015. "Regulating hate speech and freedom of expression on the Internet: Promoting tolerance and

\footnotetext{
${ }^{308} \mathrm{http} / /$ www.ijr.org.za/home/wp-content/uploads/2018/03/IJR-Barometer-Report-2017-WEB-final.pdf

${ }^{309} \mathrm{http}: / /$ www.ijr.org.za/home/wp-content/uploads/2018/03/IJR-Barometer-Report-2017-WEB-final.pdf
} 
diversity." South African Journal of Criminal Justice, 28 (3): 303- 336.

13. Cilliers, F. 2013. "The Role and Effect of Social Media in the Workplace." Northern Kentucky Law Review, 40 (3): $567-592$.

14. Coetzee, S. 2019. "A Legal Perspective on Social Media Use and Employment: Lessons for South African Educators." PER/Potchefstroom Electronic Law Journal, 22, https:// doi.org/10.17159/1727-3781/2019/v22i0a5778

15. Cohen, N. 2018. "How culture affects street-level bureaucrats' bending the rules in the context of informal payments for health care: The Israeli case." American Review of Public Administration, 48 (2): 175 - 187.

16. Commission of Employment Equity, 19th Commission of Employment Equity Annual Report 2018-2019 (Wed page) https://www. labourguide.co.za/workshop/1692-19th-cee-annual-report/file

17. Corney, A. 2014. "Unfair Dismissal Relating to the Use of Social Media - An Analysis of Case History." Canberra Law Review, 12 (1): 144 - 188.

18. Cowling, D. 2019. Social Media Statistics Australia - September 2019. https://www.socialmedianews.com.au/ social-media-statistics-australia-september-2019/ Accessed 18/10/2019.

19. Davidson, H. 2006. "Former SBS reporter Scott McIntyre repeats Anzac Day accusations on Twitter." The Guardian, 25 April.

20. Davis, M. 2015. "Social media policies: balancing individual expression, privacy and employment obligations." Privacy Law Bulletin, 12 (6): 163-166.

21. Dimitrova, K., Rahmanzadeh, S., and Lipman, J. 2013. "Justine Sacco, Fired After Tweet on Aids in Africa, Issues Apology." ABC News, Sydney, 22 December.

22. Du Toit, D. 2016. "The Right to Equality v Employer Control and Employee 'Subordination': Are Some More Equal Than Others?" Industrial Law Journal, 37 (1): 1-27.

23. Du Toit, D. et al. 2006. Labour Relations Law: A Comprehensive Guide. Durban, South Africa: LexisNexis Butterworth.

24. Dugard, J. 2015. Human Rights and the South African Legal Order. Princeton, New Jersey: Princeton University Press.

25. Duvenhage, J. 2017. Social Media in the Workplace: Legal challenges for employers and employees. Master of Law thesis, University of Notre Dame, Australia.

26. Forsyth, A. 2014. "A Thin Wall of Privacy Protection, with Gaps and Cracks: Regulation of Employees' Personal Information and Workplace Privacy in Australia." In R. Blanpaint et al. (eds.) Protection of Employees' Personal
Information and Privacy. Bulletin of Comparative Labour Law Series 88, Wolters Kluwer, pp. 7 -33.

27. French, R. 2015. "Human Rights Protection in Australia and the United Kingdom: Contrasts and Comparisons." Brief, 42 (2): 14 - 21.

28. Galligan, B., and Morton, F.L. 2006. "The Australian Exceptionalism: Rights Protection without a Bill of Rights." In T Campbell, J Goldsworthy and A Stone (eds.) Protecting Rights Without a Bill of Rights: Institutional Performance and Reform in Australia. Hampshire, England: Ashgate Publishing Limited, pp 17-39.

29. Gibson, J. 2015. "Apartheid's Long Shadow: How Racial Divides Distort South Africa's Democracy." Foreign Affairs, 94(2): $41-48$.

30. Henriques-Gomes, L. 2018. "Cricket Australia accused of sacking woman for abortion rights tweets."' The Guardian, 30 July.

31. Hill, K. 2013. “Justine Sacco's Nightmare before Christmas, Twitter-Version." Forbes, 21 December.

32. Hytner, M. 2019. "Israel Folau and Rugby Australia settle unfair dismissal claim over social media post." The Guardian, 4 December.

33. Jensen, D. C. 2018. "Does core task matter for decisionmaking? A comparative case study on whether differences in job characteristics affect discretionary street-level decision-making." Administration and Society, 50 (8): 1125 - 1147.

34. Kampmark, B. 2018. "Australian Legal Exceptionalism and the Bill of Rights." Journal for Peace and Justice Studies, $28(2): 3-26$.

35. Kampmark, B. 2017. "The Roz Ward Case: Reflections on Social Media, University Management and Free Speech." Australian Humanities Review, 62: 26 - 45.

36. Kemp, S. 2019. "Digital 2019 Global Digital Yearbook Report." Global Digital Report 2019 - We Are Social. 21 May http://wearesocial.com/global-digital-report-2019

37. Kemp, S. 2019. “Digital South Africa - DataReportal.' Global Digital Insights. January https://datareportal.com/reports/ digital-2019-south-africa Accessed 29/03/2020.

38. Lam, H. 2016. "Social media dilemmas in the employment context." Employee Relations, 38 (3): 420 - 437.

39. Levin, A. 2015. "Losing the Battle but Winning the War: Why Online Information Should be a Prohibited Ground." Canadian Labour and Employment Law Journal, 18 (2): $379-410$.

40. Lindsay, D. 2014. “The 'Right to Be Forgotten' in European Data Protection Law." In N Witzleb et al. (eds.) Emerging 
Challenges in Privacy Law: Comparative Perspectives. Cambridge, UK: Cambridge University Press, pp 290 - 338.

41. Lipsky, M. 1980. Street-Level Bureaucracy: Dilemmas of the Individual in Public Service. New York, USA: Russell Sage Foundation.

42. Lomborg, S. 2017. "A state of flux: Histories of social media research." European Journal of Communication, 32 (1): 6 - 15 .

43. Magubane, B. 1986. "The Political Economy of the South African Revolution." African Journal of Political Economy, 1 (1): 1-28.

44. Mangan, D. 2015. "A Platform for Discipline: Social Media Speech and the Workplace" February 3. SSRN: https:// ssrn.com/abstract=2559808 Accessed 29/03/2020.

45. Mangan, D. 2017. "Social media in the workplace." In D Mangan and L Gillies (eds.) The Legal Challenges of Social Media. Cheltenham, UK: Edward Elgar Publishing Limited, pp 201-221.

46. Mangan, D. 2018. "Online Speech and the Workplace: Public Right, Private Regulation." Comparative Labor Law and Policy Journal, 39 (2): 357 - 388.

47. Mann, M., and Daly, A. 2019. "(Big) data and the North-inSouth: Australia's informational imperialism and digital colonialism." Television and New Media, 20 (4): 379 - 395.

48. Manne, K. 2017. Down Girl: The Logic of Misogyny. New York, USA: Oxford University Press.

49. Mantouvalou, V. 2019. "I Lost My Job over a Facebook Post: Was that Fair? Discipline and Dismissal for Social Media Activity." International Journal of Comparative Labour Law and Industrial Relations, 35(1): 101 - 125.

50. McDonald, P., and Thompson, P. 2016. "Social Media(tion) and the Reshaping of Public/Private Boundaries in Employment Relations." International Journal of Management Reviews, 18: 69- 84.

51. Meanings and origins of Australian words and idioms. 2017. https://slll.cass.anu.edu.au/centres/andc/meaningsorigins/l Accessed 29/03/2020.

52. Mgrditchian, G. 2015. "Employment \& Social Media Privacy: Employer Justification for Access to Private Material." Rutgers Computer and Technology Law Journal, 41 (1): 108 - 133.

53. Nel, S. 2016. "Social media and employee speech: the risk of overstepping the boundaries into the firing line." Comparative and International Law Journal of Southern Africa, 49 (2): 182 - 222.

54. O’Rouke, A., Pyman, A., and Teicher, J. 2007. “The Right to Privacy and the Conceptualisation of the Person in the
Workplace: A Comparative Examination of the EU, US and Australian Approaches." International Journal of Comparative Labour Law and Industrial Relations, 23(2): 161 - 194.

55. O’Rouke, A., Pyman, A., Teicher, J., and van Gramberg, B. 2018. "Old wine in new bottles? Regulating employee social media use through termination of employment law: A comparative analysis." Common Law World Review, 47 (4): 248 - 271.

56. O’Rouke, A., Teicher, J., and Pyman, A. 2011. "Internet and Email Monitoring in the Workplace: Time for an Alternate Approach." Journal of Industrial Relations, 53 (4): 522 - 533.

57. Odeh, L.E. 2012. "A Comparative Analysis of Global North and Global South Economies." Journal of Sustainable Development in Africa, 12 (3): 338 - 348.

58. Ornstein, D. 2012. "Social Media Usage in the Workplace Around the World - Developing Law and Practices." Business Law International, 13(2): 195 - 207.

59. Papadopoulos, S. 2009. "Revisiting the Public Disclosure of Private Facts in Cyberworld." Obiter, 30 (1): 30 - 43.

60. Papworth, L. 2009. "Facebook: Active Users in Australia." 31 August http://laurelpapworth.com/facebook-activeusers-in-australia/ Accessed 29/03/2020.

61. Park, S. 2014. "Employee Internet Privacy: A Proposed Act that Balances Legitimate Employer Rights and Employee Privacy." American Business Law Journal, 51 (4): 779 - 841.

62. Pearl, C. 1958. Wild Men of Sydney. London, UK: W.H. Allen.

63. Pilkington, E. 2013. "Justine Sacco, PR executive fired over racist tweet, "ashamed."' The Guardian, 23 December.

64. Pivoras, S. and Kaselis, M. 2019. "The Impact of Client Status on Street-Level Bureaucrats' Identity and Informal Accountability." Public Integrity, 21(2): 182 - 194.

65. Plester, B. 2015. "Take it like a man!: Performing hegemonic masculinity through organizational humour." Ephemera: Theory and Politics in Organisation, 15 (3): 537 - 559.

66. Potgieter, E. and Moosa, M. 2018. 'More than a space for interracial contact: Exploring the importance of the workplace for social cohesion and reconciliation in South Africa' (Reconciliation and Development Report No 1, 2018). https://www.africaportal.org/publications/more-spaceinterracial-contact-exploring-importance-workplacesocial-cohesion-and-reconciliation-south-africa/ Accessed 29/03/2020.

67. Potgieter, E. 2017. 'South African Reconciliation Barometer Survey 2017 Report.' http://www.ijr.org.za/home/ wp-content/uploads/2018/03/IJR-Barometer-Report2017-WEB-final.pdf Accessed 29/03/2020. 
68. Potgieter, M. 2014. Social Media and Employment Law. Claremont, South Africa: Juta and Co.

69. Rapaport, P. 2013. "Social media policies and unfair dismissal." Media and Arts Law Review, 18 (2): 75 - 87.

70. Reddy, S. 2018. "Establishing a test for social media misconduct in the workplace." Journal of South African Law, 2018 (4): 789 - 819.

71. Richardson, M., Thomas, J., and Trabsky, M. 2012. "The Internet Imaginary and the Problem of Privacy." Media and the Arts Law Review, 17 (3): 257 - 268.

72. Robinson, G. "Folau 'vindicated' after calling truce, Rugby Australia says decision would give 'certainty." The Sydney Morning Herald, Sydney, 4 December.

73. Rogers, B. 2019. "Social Media and Worker Organizing under US Law." International Journal of Comparative Labour Law and Industrial Relations, 35(1): 127 - 152.

74. Roos, A. 2012. "Privacy in the Facebook Era: A South African Legal Perspective." South African Law Journal, 129 (2): 375 - 402.

75. SA population reaches 58.8 million, Department: Statistics South Africa, (Web Page, 29 July 2109) http://www.statssa. gov.za/?p=12362 Accessed 29/03/2020.

76. Sarkin, J. 1998. "The Development of a Human Rights Culture in South Africa." Human Rights Quarterly, 20(3): $628-665$.

77. Seah, D. 2016. "Social Media and Freedom of Expression in the Workplace: Is the Law and Practice in the UK Fit for Purpose?" Bristol Law Review, 2016 (3): 11-32.

78. Shaw, L. 2011. "Hate Speech in Cyberspace: Bitterness without Boundaries." Notre Dame Journal of Law, Ethics and Public Policy, 25 (1): 279 - 304.

79. Sleep, L. 2019. "Domestic violence, social security and the couple rule" (Research report, 04/2019) Sydney, NSW: ANROWS. https://d2rn9gno7zhxqg.cloudfront.net/wpcontent/uploads/2019/07/18032453/RP.17.02_Sleep_D_ RR_social-security_couple-rule.pdf Accessed 29/03/2020.

80. Sleep, L. and Tranter, K. 2018. "Social media in security decision-making in Australia: An archive of truth?" Media and Arts Law Review, 22 (4): 442 - 463.

81. Statistics South Africa, National Poverty Line 2019, (Statistical Release P0310.1, 31 July 2019) (Web page) http:// www.statssa.gov.za/publications/P03101/P031012019. pdf Accessed 29/03/2020

82. Statistics South Africa, Work and Labour Force (Web page, 26 September 2019) http://www.statssa.gov.za/?page id=737\&id=1 Accessed 29/03/2020
83. Stewart, A. 2018. Stewart's Guide to Employment Law. Annandale, NSW: Federation Press.

84. Stewart, A. et al. 2016. Creighton \& Stewarts Labour Law. Annandale, NSW: Federation Press.

85. Stiegler, C. 2015. "Developments in Employment and Social Media." Business Lawyer, 71 (1): 321 - 332.

86. Sunstein, C.R. 2018. \#Republic: Divided Democracy in the Age of Social Media. Princeton, New Jersey: Princeton University Press.

87. Taylor, M. et al. 2016. "Avoiding the misuse of social media by employees." Network Security, 2016 (5): 8 - 11.

88. Tchamyou, V. S., Erreygers, G., and Cassimon, D. 2019. "Inequality, ICT and financial access in Africa." Technological Forecasting and Social Change, 139: 169 - 184.

89. Thornthwaite, L. 2013. "Social media, unfair dismissal and the regulation of employees' conduct outside work." Australian Journal of Labour Law, 26 (2): 164 - 184.

90. Thornthwaite, L. 2016. "Social Media and Work An emerging privacy." Precedent, 135: 8 - 13.

91. Thornthwaite, L. 2018. "Social Media and dismissal: Towards a reasonable expectation of privacy?" Journal of Industrial Relations, 60 (1): 119 - 136.

92. Tomsen, S. 2017. "Masculinity and homophobic violence in Australia's recent past." Sexuality and Culture, 21 (3): 813 - 829.

93. Van de Merwe, D. et al. 2016. Information and Communications Technology Law. Johannesburg, South Africa: LexisNexis (Pty) Ltd.

94. Van Dissel, B. 2014. "Social media and the employee's right to privacy in Australia." International Data Privacy Law, 4 (3): 222 - 234.

95. Van Gramberg, B., Teicher, J., and O’Rouke, A. 2014. “Managing electronic communications: a new challenge for human resource managers." International Journal of Human Resource Management, 25 (16): 2234 - 2252.

96. Vine, J. 2009. The Larrikin Paradox: An Analysis of Larrikinism's Democratic Role in Australian Journalism. Ph.D. thesis, Royal Melbourne Institute of Technology University, Melbourne.

97. Wagstaff, E. and Tranter, K. 2014. "Taking Facebook at face value: The Refugee Review Tribunal's use of social media evidence." Australian Journal of Administrative Law, 21: 172 - 186

98. World Bank, Poverty and Equity Brief South Africa October 2019, (Web page, October 2019) https://databank.worldbank.org/data/download/ 
poverty/33EF03BB-9722-4AE2-ABC7-AA2972D68AFE/

Global_POVEQ_ZAF.pdf Accessed 29/03/2020.

99. Wragg, P. 2015. "Free Speech Rights at Work: Resolving the Differences between Practice and Liberal Principle." Industrial Law Journal, 44 (1): 1 - 28.

100. 'Sensis Social Media Report,' Sensis (Web Page, 16 October 2018) https://www.sensis.com.au/about/our-reports/ sensis-social-media-report Accessed 29/03/2020.

101. 'The Future is Ours,' South African History Archives (Web page, 2019) http://www.saha.org.za/youth/the_future_ is_ours.htm Accessed 29/03/2020.

102. 'Yellow Social Media Report 2018,' Yellow (Web Page, 16 October 2018) <https://www.yellow.com.au/wpcontent/uploads/2018/06/Yellow-Social-Media-Report2018-Consumer.pdf Accessed 29/03/2020.

\section{LEGISLATION}

\section{AUSTRALIAN LEGISLATION}

Charter of Human Rights and Responsibilities Act 2006 (Vic). Commonwealth of Australia Constitution Act 1900 (Cth). Fair Work Act 2009 (Cth).

Human Rights Act 2004 (ACT).

Human Rights Act 2019 (Qld).

Privacy Act 1988 (Cth).

\section{SOUTH AFRICAN LEGISLATION}

Basic Conditions of Employment Act 1997 (South Africa).

Broad-Based Black Economic Empowerment Act 53 of 2003 (South Africa).

Constitution of the Republic of South Africa 1996 (South Africa).

Employment Equity Act 55 of 1998 (South Africa).

Labour Relations Act 1995 (South Africa).

Promotion of Equality and Prevention of Unfair Discrimination Act 4 of 2000 (South Africa).

Regulation of Interception of Communications and Provision of Communication Act 2002 (South Africa).

Skills Development Act 97 of 1998 (South Africa).

\section{CASE LAW}

\section{AUSTRALIAN CASES}

Anders v The Hutchins School [2016] FWC 241.

Anthony Dekort v John River Tavern Pty Ltd [2010] FWA 3389.

Australian Broadcasting Corporation v Lenah Game Meats Pty Ltd (2001) HCA 63.

Banerji and Comcare (Compensation) [2018] AATA 892.

Banerji and Comcare [2018] AATA 892.

Banerji v Bowls (2013) FCAA 1052.

Bowden v Ottrey Homes - Cobram \& District Retirement Village Inc T/A Ottrey Lodge [2012] FWA 6468.

Chief of the Defence Force $v$ Gaynor [2017] FCAFC 41.

Clint Remmert v Broken Hill Operations Pty Ltd T/A Rasp Mine [2016] FWC 6036.

Comcare v Banerji [2019] HCA 23.

Construction, Forestry, Mining and Energy Union v Oaky Creek Coal Pty Ltd [2017] FWC 5380.

Daniel Starr v Department of Human Services [2016] FWC 1460.

Dover Ray v Real Insurance Pty Ltd [2010] FWA 8544.

Fitzgerald $v$ Smith T/A Escape Hair Design (2010) FWA 7358.

Gaynor v Chief of the Defence Force (no 3) [2015] FCA 1370.

Gee v Tasmanian Ports Corporation Pty Ltd t/a Tasports [2017] FWC 31.

Isileli "Israel" Folau v Rugby Australia Limited \& Anor, MLG2486/2019.

Judith Wilkinson-Reed v Launtoy Pty Ltd T/A Launceston Toyota [2014] FWC 644.

Jurecek v Director, Transport Safety Victoria (2006) 200 IR 123.

Kalaba v Commonwealth of Australia [2004] FCA 763.

Linfox Australia Pty Ltd v Stutsel [2012] FWAFB 7097. Little v Credit Corp Group Limited T/A Credit Corp Group [2013] FWC 9642.

Lukazsewski v Capones Pizzeria [2009] AIRC 280.

Luke Colwell v Sydney International Container Terminals Pty Ltd [2018] FWC 174. 
Marc Waters v Mt Arthur Coal Pty Limited T/A Mt Arthur Coal Pty Limited [2018] FWC 3285.

Mayberry v Kijani Investments Pty Ltd ATF The Dawe Investments Trust Subway Wallsend T/A Subway [2011] FWA 3496.

McDiarmid v Commissioner of Police [2012] NSWIRComm 100

McIntyre v Special Broadcasting Services Corporation T/A SBS Corporation [2015] FWC 6768.

Mitchell v HWE Mining Pty Ltd [2012] FWA 2721.

Mr Antony Dekort v Johns River Tavern Pty Limited T/A Blacksmiths Inn Tavern [2010] FWA 3389.

Mr Rodney Fussell v Sydney Trains [2019] FWC 1182.

Mrs Robyn Vosper v Solibrooke Pty Ltd T/A Angie's Cake Emporium [2016] FWC 1168.

Ms Kim Fallens v Serco Australia Pty Ltd T/Z Serco Acacia Prison [2015] FWC 8394.

Ms Nektaria Natoli v Anglian Community Services $t / a$ Anglicare [2018] FWC 2180.

Naresh Connolly-Manga v Global Mining Services Pty Ltd [2019] FWC 1097.

O'Keefe v William Muir's Pty Ltd T/A Troy Williams The Good Guys [2011] FWA 5311.

Pearson v Linfox Australia Pty Ltd (2014) FWC 446.

Queensland Rail Transit Authority T/A Queensland Rail v Australian Rail, Tram and Bus Industry Union [2018] FWC 6116.

Rani v Limitless Ventures Toscas Pty Ltd [2015] FWC 6429.

Renton v Bendigo HealthCare Group [2016] FWC 9089.

Rodney Fussell v Sydney Trains [2019] FWC 1182.

Rombola v Rail Commissioner [2017] FWC 194.

Sharon Bowker \& Others v DP World Melbourne Limited T/A DP World Maritime Union of Australia [2014] FWCFB 9227.

Singh v Aerocare Flight Support Pty Ltd [2016] FWC 6186. Somogyi v LED Technologies [2017] FWC 1966.

Stephen Campbell v Qube Ports Pty Ltd T/A Qube Ports \& Bulk [2017] FWC 1211.

Stutsel v Linfox Australia Pty Ltd [2011] FWA 8444.

Tasmanian Ports Corporation Pty Ltd t/a Tasports v Mr Warwick Gee [2017] FWCFB 1714.
United Firefighters' Union of Australia v Metropolitan Fore and Emergency Services Board [2017] FWC 3274.

Victoria Park Racing and Recreation Grounds Co Ltd v Taylor (1937) 58 CLR 479.

\section{UNITED KINGDOM CASES}

Weeks v Everything Everywhere Ltd ET/2503016/2012. Smith v Trafford Housing Trust [2012] EWHC 3221 (Ch). Game Retail Limited v Laws, Appeal No UKEAT/0188/14/DA. Teggart v Teletech [2004] IRLR 625.

Crisp v Apple ET1500258/2011.

Preece v JD Wetherspoons plc ET/2104806/102011.

\section{UNITED STATES CASES}

American Med Response of Conn. NLRB Reg 34 No 34-CA-12576.

Karl Knauz Motors, Inc d//b/c Knauz BMW and Robert Becker, 358, NLRB No 164 (2012).

Ehling v Monmouth-Ocean Hospital Service Corp, 961 F. Supp.2d 659,669 (D.N.J. 2013).

Pietrylo v Hillstone Restaurant Group No. 06-5754 (FSH), 2009 WL 3128420 (D.N.J. Sept 2005, 2009).

Hispanics United of Buffalo v Ortiz 359 NLRB No 37 (2011).

\section{SOUTH AFRICAN CASES}

Ahmad Mahri v Mather Dangor Financial Services [2018] CCMA GAJB15475-18.

Amakhosi Radebe v JD Group (Pty) Ltd [2014] CCMA GAJB12297-14.

Anthony Mark Bird v Rand Mutual Admin Services (Pty) Ltd [2017] CCMA GAJB15348-17.

Arthur Leach v Suzuki JHB South MINT 44570 D. Aubrey Mabaso v UTI South Africa (Pty) Ltd GPRFBC 35409. Beaurain v Martin NO and others (C16/2012) [2014] ZALCCT 16.

Booi v Wonderstone [2013] CCMA NWKD963-13.

Broadcasting, Electronic, Media \& Allied Workers Union obo Msimang v South African Broadcasting Corporation [2017] 11 BALR 1170 (CCMA).

Cantamessa and Edcon Group (2017) 38 ILJ 1909 
(CCMA).

CEPPWAWU obo Dietlof v Frans Loots Building Material Trust t/a Pennypinchers [2016] CCMA ECPE7247-15. Constance Hleza v Edcon (Pty) Ltd [2014] CCMA GAEK1469-14. Crisna Roux v SBF Services (Pty) Ltd [2017] CCMA GATW8998-17.

Crown Chickens (Pty) Ltd t/a Rocklands Poultry v Kapp and Others (2002) 23 ILJ 863 (LAC).

Dagane v SSSBC and others JR 2219/14 [2018] ZALCJHB 114.

Daniel Rayman Nqani v Els Cole Brioche [2015] CCMA ECPE4540-15.

Davina Shee v Greystone Trading CC t/a Absolote Pets [2012] CCMA WECT 2852-12.

Desigan Muthaya v First National Bank (FNB) [2018] CCMA GAJB15475-18.

Dewoonarain v Prestige Car Sales (Pty) Ltd t/a Hyundai Ladysmith 20137 BALR 689 (MIBC).

EAMWUSA obo Duncan van Wyk v Dart Stationers CC [2011] CCMA WECT14283-11.

FAWU obo Martin Du Preez v Casidra (Pty) Ltd t/a Aanhalt Boerdery [2013] CCMA WEGE 1417-13.

FAWU obo Matlaila, Sammy v Tiger Brands Field Sales (Pty) Ltd [2014] CCMA GAJB634-14.

FAWU obo Myeni, Ntokozo v Imperial Retail Solutions [2016] CCMA KNDB2662-16.

FAWU obo Ngomane, Thabiso v Radisson BLU Hotel Sandton [2018] CCMA GAJB20280-18.

FOSAWU obo Koka, Daniel v Goldreef City Casino [2011] CCMA GAJB15215-11.

Fredericks v Jo Borkett Fashions [2012] 1 BALR 28 (CCMA). Galya Brickhill v Ellerines Furnishers [2012] CCMA GAJB19322-12.

George Roderick Molale v Bosasa Security (Pty) Ltd [2017] CCMA GAJB27050-17.

Hanniker v One and Only Cape Town [2017] CCMA WECT4369-17.

Happiness Harting v Container World (Pty) Ltd [2015] CCMA GAEK9537-15.

Iteseng Joseph Nkgwang v Eskom Holdings Ltd MEMP351. Jikela v Smit Amandla Marine [2012] CCMA WECT 16547-12.
Johannes Makganthe Ngoepe v Quemic (Pty) Ltd [2015] CCMA GAJB4016-15.

Jolanda Roose v Netcare 911 [2016] CCMA ECPE405-16.

Kenneth Marshal Alexander v Ebesa Architects (Pty) Ltd [2015] CCMA WECT19446-15.

Khanya Zowia Nduma v Fowkes Brothers (Pty) Ltd [2018] CCMA WECT 5340-18.

Khumalo v Holomisa 20025 SA 401 (CC).

Le Roux v Dey 20113 SA 274 (CC).

Lindiwe Sweetness Shozi v Standard Bank [2017] CCMA KNDB6956-17.

Lindokuhle Ngcobo v EOH Avanti (Pty)Ltd t/a Highveld PFS [2014] CCMA GAJB 20141-14.

Lucia Nhlapo v Delta EMD [2013] CCMA MP5131-13. Lucienne- Anne Haviga v SAA (SOC) Ltd [2014] CCMA GAEK7750-14.

Luxolo Kobo v Sea Truworths (Pty) Ltd WECT [2018] CCMA 13962-18.

Mafabatho Ndhlovu v Adve Tech Copperleaf College [2018] CCMA GATW 12969-18.

Mahoro v Indube Staffing Solutions [2012] 4 BALR 395 (CCMA).

Mandla Zamokwakhe Magubane v De Heus [2017] CCMA KNPM2101-17.

Masemola $v$ Commission for Conciliation, Mediation and Arbitration and Others (JR1025/2013) [2016] ZALCJHB 183.

MATUSA obo Paulse v JD Kirsten Boedery (Pty) Ltd [2018] CCMA WECT17777-18.

Media Workers Association of SA obo Mvemve and Kathorus Community Radio 201031 ILJ 2217 (CCMA).

Melody Adendorffv The Leadership Development Institute [2010] CCMA ECEL2327-10.

Makhanya $v$ St Gobain [2019] 7 BALR 720 (NBCCI).

Melusi Nelson Mthabela v Arcelor Mittal SA Ltd MEKN9239.

Mmakwena Martin Mokgehle v Imvula Quality Protection [2017] CCMA GAJB24628-17

Moreblessing Ndudzo v Studio 05 House of Fashion [2011] CCMA GAJB28706-11. 
Motloung v The Market Theatre Foundation [2011] CCMA GAJB 4458-11.

M Paulse v Department of Health-Western Cape [2018] CCMA PSHS10-17/18.

Mr J Ludick v Vodacom Group Ltd (operating as Vodacom) [2018] CCMA WECT16371.

Mr T Mabele v SGRP Meridian (Pty) Ltd [2016] CCMA WECT: 4669- 16.

Ms Muthoni Kimani v Cape Peninsula University of Technology [2017] CCMA WECT 18824-17.

Nanthus Augustus v Mass Discounters (Pty) Ltd [2015] CCMA ECPE79-15.

NASUWU obo Ngxwana v M Red Alert Cleaning and Security [2016] CCMA ECEL4931-16.

Nathaniel Arelisky v Van Wyk Da Silva Trust t/a Ocean Basket Table View [2010] CCMA WECT16930-10.

National Union of Food, Beverage, Wine, Spirits and Allied Workers Union obo Arendse / Consumer Brands Business Worcester, a Division of Pioneer Foods (Pty) Ltd [2013] CCMA WECT16781-13.

National Union of Metalworkers of South Africa obo Zulu / GUD Holdings (Pty) Ltd MIDB12660.

National Union of Metalworkers of South Africa obo Victor and Warikker v Aveng Trident Steel (Pty) Ltd MEPE 1794. NEHAWU obo Motseme, I and 1 other $v$ Tsebo Holdings and Operations (Pty) Ltd t/a Fedics [2017] CCMA NC26-17.

NEHAWU obo Obakeng Victor Tilodi $v$ Commissioner T Ndzombane, Department of Health and Public Health \& Social Development Sectoral Bargaining Council C30/15.

NEHAWU obo Sifiso Cyril Dlamini v Dept of Social Development-Kwazulu Natal PSHS901.

Noluthando Gumede v Mutual and Federal [2014] CCMA GAJB9817-14.

NTM obo Ms C Ganger v Bidair Services (Pty) Ltd [2015] CCMA WECT 1273-15.

NUM obo Godloza, Sivuyile Yalela v Harmony Gold Mining Company Ltd [2012] CCMA FS2022-12.

NUMSA obo Eugene Patterson v PFG Building Glass CHEM516-16/17.

NUMSA obo Ishmael Mpe Jogom v G4S Correction Services (Bloemfontein) (Pty) Ltd [2016] CCMA FSBF5052-16.
NUMSA obo Komane, Mike v Middelburg Ferrochrome MEMP351.

O'Keefe v Argus Printing and Publishing Company Limited 19543 SA 244 (Constitutional Court) 247.

Palesa Petronella Motol v Democratic Alliance (DA) [2017] CCMA LP1723-17.

Pamela Matiso v Nelson Mandela Tourism [2012] CCMA ECPE2825-12.

Phillip Madisha v Sandton Plant Hire (Pty) Ltd [2018] CCMA GAJB 10432-18.

Pontsho Maja v Glencore Lion Smelter [2016] CCMA LP3649-16.

Portia Ndlovu-Nzama v Ithala Development Finance Corporation [2011] CCMA KNDB11884-11.

Princess Mlala v Bidvest Vericon and Avon [2017] CCMA GAEK3588-17.

Praxydis Lungile Dladla v E SAT (E.TV) [2011] CCMA GAJB948-11.

Robert Naysmith $v$ Merchant SA (Pty) Ltd [2015] CCMA GAJB8124-15.

S v Mamabolo (E TV Intervening) 20013 SA 409 (CC).

SACCAWU obo Gustuv Cholofeco Mokhothu v Edcon (Pty) Ltd [2014] CCMA FSWK824-14.

SACWU obo Nkala Sipho v Sasol Synfuels [2017] MPCHEM355-15/16.

SACCAWU obo Prescilla Matshidiso Motshegoa v Mass Discounters (Pty) Ltd t/a Game Stores [2013] CCMA GAJB11646-13.

Samuel Mokwoane Shayi v Quality Pallets CC [2015] CCMA GAJB4751-15.

SASSAWU obo Ballim, Yasmin v North West Provincial Legislature [2013] CCMA NWKD2792-13.

SATAWU obo Sam and Two Others $v$ Ikhethele Terminal Services (Pty) Ltd [2012] CCMA WECT12982-12.

Sedick and Another v Krisray [2011] 8 BALR 879 (CCMA) . Simphiwe Given Mbhele v Shoprite [2015] CCMA KNDB1959-15. Sithembile Portia Zulu v SATAWU [2015] CCMA MP8164-15. Sithembiso Promise Mavundla v Merchants SA (Pty) Ltd a Dimension Data Company [2019] CCMA GAJB7904-19. 
Smit v Partners in Sexual Health (Non-profit) (2011) 32 ILJ 1470 (CCMA).

SOCRAWU obo Elroy Bibby v KSM Distributors [2018] BC PERFBC 49968.

South African Breweries (Pty) Ltd v Hansen and Others (2017) 38 ILJ 1766 (LAC).

South African Revenue Service v Commission for Conciliation, Mediation and Arbitration and Others (2017) 38 ILJ 97 (CC).

Stephen Devasagium Andrew v Pick n Pay Supply Chain [2014] CCMA GAJB5317-14.
Suretha Nass v Little Green Beverages (Pty) Ltd [2017] CCMA ECEL2930-17.

Thamsanqa David Ntshangase v MCFI International SA Pty Ltd [2015] CCMA KNDB10251-15.

Thando Templeton Maku v Department of Social Development - Western Cape [2017] CCMA PSHS330-16/17.

Toni Muir v Neo Africa [2012] CCMA GAJB 7546-12.

UASA obo Siviwe Bokuva v Shoprite Checkers Ltd [2017] CCMA ECEL2040-17.

William Kerekere v Onelogix [2015] CCMA KNDB964915.

Willie B Botha $v$ Bid Air Service [2015] CCMA ECPE3142-15. WOCOFO obo Siphokazi Pitseng v Rayal Trading Pty Ltd [2013] CCMA GATW11253-13

\section{APPENDIX 1: AUSTRALIAN SAMPLE}

\begin{tabular}{|l|}
\hline Anders v The Hutchins School [2016] FWC 241 \\
\hline Bowden v Ottrey Homes - Cobram \& District Retirement Village Inc T/A Ottrey Lodge [2012] FWA 6468 \\
\hline Banerji and Comcare (Compensation) [2018] AATA 892 \\
\hline Banerji v Bowls (2013) FCAA 1052 \\
\hline Chief of the Defence Force v Gaynor [2017] FCAFC 41 \\
\hline Clint Remmert v Broken Hill Operations Pty Ltd T/A Rasp Mine [2016] FWC 6036 \\
\hline Comcare v Banerji [2019] HCA 23 \\
\hline Construction, Forestry, Mining and Energy Union v Oaky Creek Coal Pty Ltd [2017] FWC 5380 \\
\hline Daniel Starr v Department of Human Services [2016] FWC 1460 \\
\hline Dover Ray v Real Insurance Pty Ltd [2010] FWA 8544 \\
\hline Fitzgerald v Smith T/A Escape Hair Design (2010) FWA 7358 \\
\hline Gaynor v Chief of the Defence Force (no 3) [2015] FCA 1370 \\
\hline Gee v Tasmanian Ports Corporation Pty Ltd t/a Tasports [2017] FWC 31 [36] \\
\hline Judith Wilkinson-Reed v Launtoy Pty Ltd T/A Launceston Toyota [2014] FWC 644 [13] \\
\hline Jurecek v Director of Transport Safety Victoria [2016] VSC 285 \\
\hline Linfox Australia Pty Ltd v Stutsel [2012] FWAFB 7097 \\
\hline Little v Credit Corp Group Limited T/A Credit Corp Group [2013] FWC 9642 \\
\hline Lukazsewski v Capones Pizzeria [2009] AIRC 280 \\
\hline Luke Colwell v Sydney International Container Terminals Pty Ltd [2018] FWC 174 \\
\hline Marc Waters v Mt Arthur Coal Pty Limited T/A Mt Arthur Coal Pty Limited [2018] FWC 3285 \\
\hline Mayberry v Kijani Investments Pty Ltd ATF The Dawe Investments Trust Subway Wallsend T/A Subway [2011] FWA 3496 \\
\hline McDiarmid v Commissioner of Police [2012] NSWIRComm 100 \\
\hline
\end{tabular}




\begin{tabular}{|l|}
\hline Mitchell v HWE Mining Pty Ltd [2012] FWA 2721 \\
\hline Mr Antony Dekort v Johns River Tavern Pty Limited T/A Blacksmiths Inn Tavern [2010] FWA 3389 \\
\hline Mr Rodney Fussell v Sydney Trains [2019] FWC 1182 \\
\hline Mrs Robyn Vosper v Solibrooke Pty Ltd T/A Angie's Cake Emporium [2016] FWC 1168 \\
\hline Ms Kim Fallens v Serco Australia Pty Ltd T/Z Serco Acacia Prison [2015] FWC 8394 \\
\hline Ms Nektaria Natoli v Anglian Community Services t/a Anglicare [2018] FWC 2180 \\
\hline Naresh Connolly-Manga v Global Mining Services Pty Ltd [2019] FWC 1097 \\
\hline O'Keefe v William Muir's Pty Ltd T/A Troy Williams The Good Guys [2011] FWA 5311 \\
\hline Pearson v Linfox Australia Pty Ltd (2014) FWC 446 \\
\hline Queensland Rail Transit Authority T/A Queensland Railv Australian Rail, Tram and Bus Industry Union [2018] FWC 6116 \\
\hline Rani v Limitless Ventures Toscas Pty Ltd [2015] FWC 6429 \\
\hline Renton v Bendigo HealthCare Group [2016] FWC 9089 \\
\hline Rombola v Rail Commissioner [2017] FWC 194 \\
\hline Sharon Bowker \& Others v DP World Melbourne Limited T/A DP World Maritime Union of Australia [2014] FWCFB 9227 \\
\hline Singh v Aerocare Flight Support Pty Ltd [2016] FWC 6186 \\
\hline Somogyi v LED Technologies [2017] FWC 1966 \\
\hline Stephen Campbell v Qube Ports Pty Ltd T/A Qube Ports \& Bulk [2017] FWC 1211 \\
\hline Stutsel v Linfox Australia Pty Ltd [2011] FWA 8444 \\
\hline Tasmanian Ports Corporation Pty Ltd t/a Tasports v Mr Warwick Gee [2017] FWCFB 1714 \\
\hline United Firefighters' Union of Australia v Metropolitan Fore and Emergency Services Board [2017] FWC 3274 \\
\hline
\end{tabular}

\section{APPENDIX 2: SOUTH AFRICAN SAMPLE}

\begin{tabular}{|l|}
\hline Ahmad Mahri v Mather Dangor Financial Services [2018] CCMA GAJB15475-18 \\
\hline Amakhosi Radebe v JD Group (Pty) Ltd [2014] CCMA GAJB12297-14 \\
\hline Anthony Mark Bird v Rand Mutual Admin Services (Pty) Ltd [2017] CCMA GAJB15348-17 \\
\hline Arthur Leach v Suzuki JHB South [2015] MIBC MINT 44570 D \\
\hline Aubrey Mabaso v UTI South Africa (Pty) Ltd GPRFBC 35409 \\
\hline Beaurain v Martin NO and others (C16/2012) [2014] ZALCCT 16 \\
\hline Booi v Wonderstone [2013] CCMA NWKD963-13 \\
\hline Broadcasting, Electronic, Media \& Allied Workers Union obo Msimang v South African Broadcasting Corporation [2017] \\
\hline Cantamessa and Edcon Group (2017) 38 ILJ 1909 (CCMA) \\
\hline CEPPWAWU obo Dietlof v Frans Loots Building Material Trust t/a Pennypinchers [2016] CCMA ECPE7247-15 \\
\hline Constance Hleza v Edcon (Pty) Ltd [2014] CCMA GAEK1469-14 \\
\hline Crisna Roux v SBF Services (Pty) Ltd [2017] CCMA GATW8998-17 \\
\hline Dagane v SSSBC and others JR 2219/14 [2018] ZALCJHB 114 \\
\hline
\end{tabular}




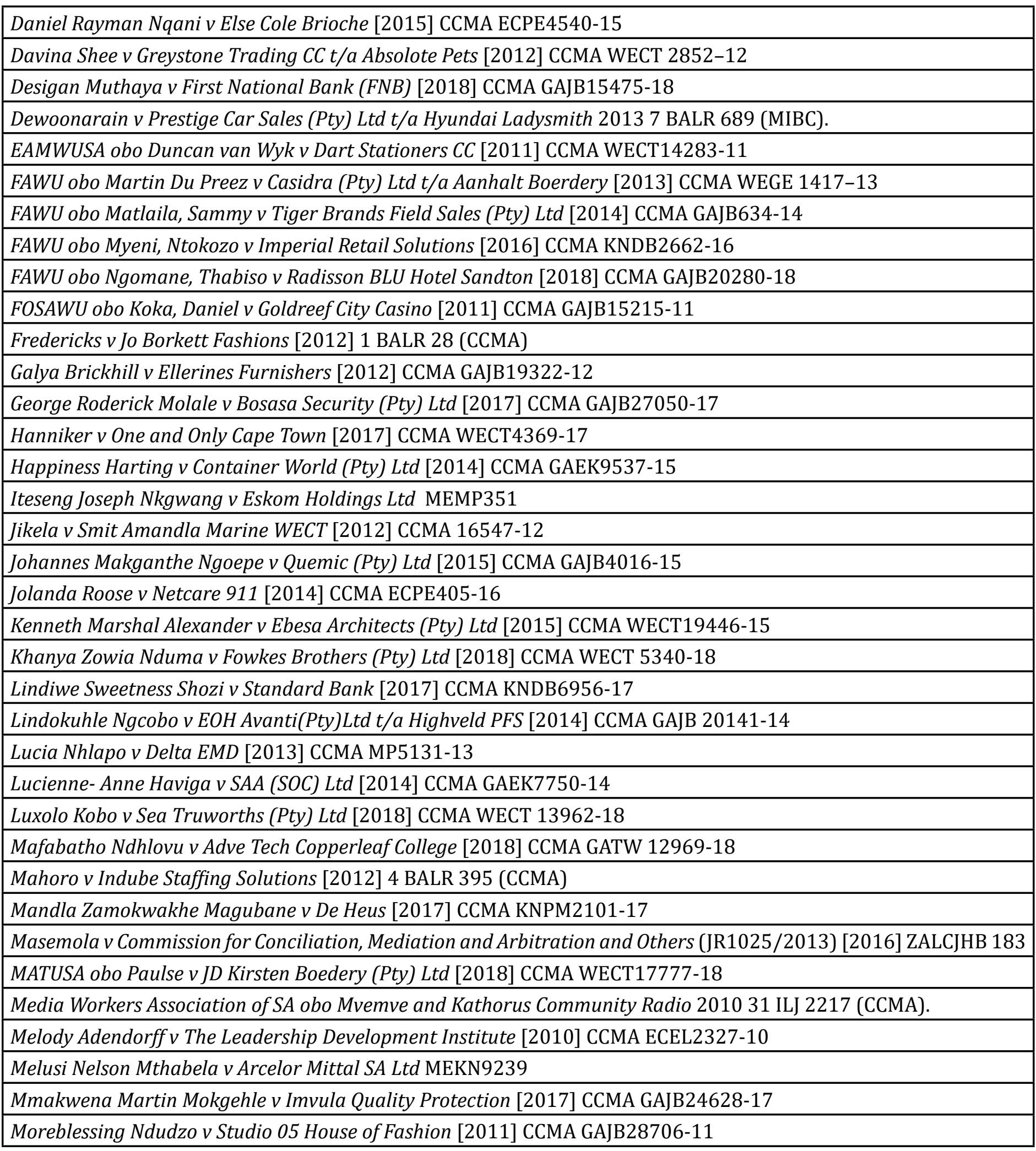




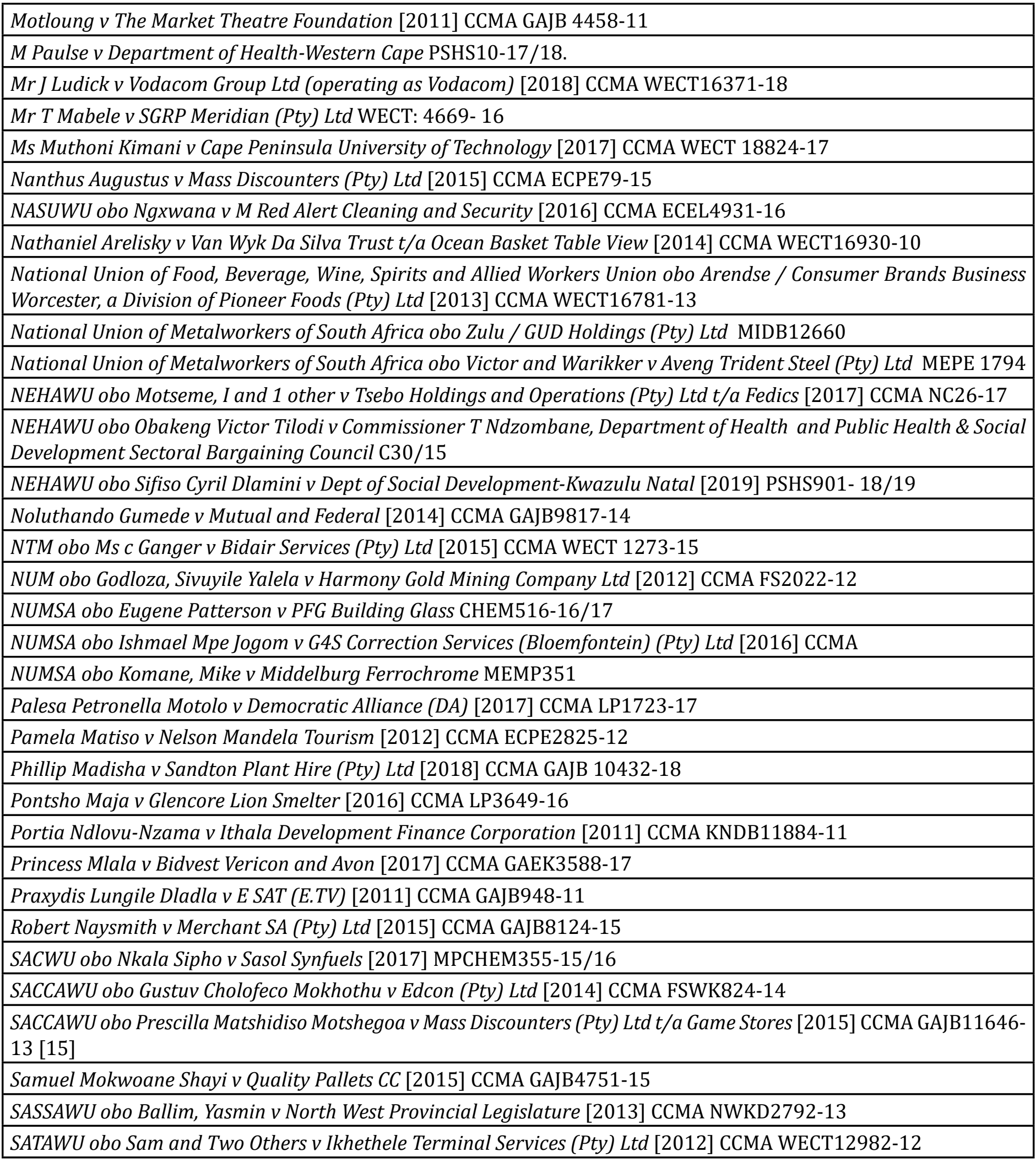




\begin{tabular}{|l|}
\hline Sedick and Another v Krisray [2011] 8 BALR 879 (CCMA) \\
\hline Simphiwe Given Mbhele v Shoprite [2015] CCMA KNDB1959-15 \\
\hline Sithembile Portia Zulu v SATAWU [2015] CCMA MP8164-15 \\
\hline Sithembiso Promise Mavundla v Merchants SA (Pty) Ltd a Dimension Data Company [2019] CCMA GAJB7904-19 \\
\hline Smit v Partners in Sexual Health (Non-profit) (2011) 32 ILJ 1470 (CCMA) \\
\hline SOCRAWU obo Elroy Bibby v KSM Distributors [2018] BC PERFBC 49968 \\
\hline Stephen Devasagium Andrew v Pick $n$ Pay Supply Chain [2014] CCMA GAJB5317-14 \\
\hline Suretha Nass v Little Green Beverages (Pty) Ltd [2017] CCMA ECEL2930-17 \\
\hline Thamsanqa David Ntshangase v MCFI International SA Pty Ltd [2015] CCMA KNDB10251-15 \\
\hline Thando Templeton Maku v Department of Social Development - Western Cape PSHS330-16/17 \\
\hline Toni Muir v Neo Africa [2012] CCMA GAJB 7546-12 \\
\hline UASA obo Siviwe Bokuva v Shoprite Checkers Ltd [2017] CCMA ECEL2040-17 \\
\hline William Kerekere v Onelogix [2015] CCMA KNDB9649-15 \\
\hline Willie B Botha v Bid Air Services [2015] CCMA ECPE3132-15 \\
\hline WOCOFO obo Siphokazi Pitseng v Rayal Trading Pty Ltd [2013] CCMA GATW11253-13 \\
\hline
\end{tabular}

